Original article

\title{
Synthesis of novel substituted purine derivatives and identification of the cell death mechanism
}

\author{
Zeynep Demir ${ }^{\mathrm{a}, 1}$, Ebru Bilget Guven ${ }^{\mathrm{b}, 1}$, Suheyla Ozbey ${ }^{\mathrm{c}}$, Canan Kazak ${ }^{\mathrm{d}}$, \\ Rengul Cetin Atalay ${ }^{\text {b, *, Meral Tuncbilek }}{ }^{\text {a, * }}$ \\ a Department of Pharmaceutical Chemistry, Faculty of Pharmacy, Ankara University, 06100 Ankara, Turkey \\ b Department of Molecular Biology and Genetics, Bilkent University, 06800 Ankara, Turkey \\ ${ }^{c}$ Department of Engineering Physics, Faculty of Engineering, Hacettepe University, 06800 Beytepe, Ankara, Turkey \\ d Department of Physics, Faculty of Arts and Sciences, Ondokuz Mayı University, 55139 Kurupelit, Samsun, Turkey
}

\section{A R T I C L E I N F O}

\section{Article history:}

Received 24 November 2013

Received in revised form

19 September 2014

Accepted 29 October 2014

Available online 30 October 2014

\section{Keywords:}

Adenine

Purine derivatives

Cytotoxic activity

Senescence

Hepatocellular carcinoma

\begin{abstract}
A B S T R A C T
Novel 9-(substituted amino/piperazinoethyl)adenines (4-12), 6-(substituted piperazino/amino)purines (15-27), 9-( $p$-toluenesulfonyl/cyclopentyl/ethoxycarbonylmethyl)-6-(substituted amino/piperazino)purines $(\mathbf{2 8}-\mathbf{3 4}, \mathbf{3 6}, \mathbf{3 7}, \mathbf{3 8}-\mathbf{4 1})$ were synthesized and evaluated initially for their cytotoxic activities on liver Huh7, breast T47D and colon HCT116 carcinoma cells. $\mathrm{N}^{6}$-(4-Trifluoromethylphenyl)piperazine derivative (17) and its 9-(p-toluene-sulfonyl)/9-cyclopentyl analogues $(\mathbf{2 8}, \mathbf{3 6})$ had promising cytotoxic activities. Compounds 17, 28 and $\mathbf{3 6}$ were further analysed for their cytotoxicity in a panel of a liver cancer cell lines. The compound $\mathbf{3 6}$ had better cytotoxic activities $\left(\mathrm{IC}_{50} \leq 1 \mu \mathrm{M}\right)$ than the nucleobase 5 -FU and nucleosides fludarabine, cladribine, and pentostatine on Huh7 cells. Cytotoxicity induced by $\mathbf{3 6}$ was later identified as senescence associated cell death by SA- $\beta-$ Gal assay.
\end{abstract}

(C) 2014 Elsevier Masson SAS. All rights reserved.

\section{Introduction}

Nucleobase analogues, which are structurally, metabolically and pharmacodynamically similar, are known to have different biological activities [1]. These diverse effects have been reported to be associated with anti-cancer, anti-viral, anti-fungal and antibacterial activities due inhibition of the enzymes involved in cell proliferation [2-24]. The nucleobase analogues induce apoptosis during growth and division, which is a common inhibitory mechanism observed in the presence of these molecules [25]. A wellknown pioneer fluorinated nucleobase analogue, 5-fluorouracil, is highly preferred in clinics for the treatment of various cancers [26]. Later, other pyrimidine analogues such as arabinofuranosyl cytidine (Ara-C) and gemcitabine have been identified as antimetabolite chemotherapeutic agents in cancer [1]. Purine derivatives, 6mercaptopurine and 6-thioguanine have been used as an inhibitor of nucleic acid metabolism in paediatric acute lymphoblastic leukaemia [27]. Furthermore purine nucleoside analogues such as

\footnotetext{
* Corresponding authors.

E-mail addresses: rengul@bilkent.edu.tr (R.C. Atalay), tuncbile@pharmacy. ankara.edu.tr (M. Tuncbilek).

${ }^{1}$ These authors contributed equally to this work.
}

fludarabine, cladribine, and pentostatine, emerged as a group of antimetabolites against haematological malignancies in clinics [28].

Nucleoside analogues interfere with the integrity of DNA by impairing dNTP pools and ultimately DNA synthesis through ribonucleotide reductase (RR) inhibition [29]. Due to the altered DNA integrity, which is detected as damaged by cellular machinery, the treatment with nucleoside analogues induces apoptosis [1]. There are also nucleoside analogues such as toyocamycin and decitabine, which have been reported to induce senescence, associated cell death $[30,31]$. Recently senescence-associated cell death, which is a cellular event in tumour development and progression as well as treatment, was reported as premature senescence in cancer cells [32]. Therefore, senescence induced cell death through prosenescence therapy is currently the target of small molecule inhibitors [33,34].

Primary liver cancer, hepatocellular carcinoma (HCC), is the sixth most common and the third lethal cancer [35]. Sorafenib, a kinase inhibitor, is the only FDA approved drug for HCC treatment and extends the mean survival of the patients only for 3 months [36]. Thus, it is essential to discover new chemotherapeutic agents for the treatment of this cancer. Here, we synthesized a series of 9substituted adenines (4-12), 6-substituted purines (15-27) and 
6,9-disubstituted purine analogues (28-34, 36-41) and evaluated their cytotoxic activities against liver (Huh7), colon (HCT116), and breast (T47D) carcinoma cell lines; and the most active purine analogues $(\mathbf{1 7}, \mathbf{2 8}$, and $\mathbf{3 6}$ ) were further tested on a panel of liver cancer cells. Moreover, we further characterized the most bioactive compound 36 an agent inducing senescence associated cell death with a remarkable cytotoxicity $\left(\mathrm{IC}_{50} \leq 1 \mu \mathrm{M}\right)$.

\section{Result and discussion}

\subsection{Chemistry}

The synthesis of the 9-(substituted amino/piperazinoethyl) adenine derivatives 4-12 was carried out starting from commercially available adenine (1) (Scheme 1 ). The base catalysed nucleophilic addition of $\mathbf{1}$ to ethylene carbonate afforded 9-(2hydroxyethyl)-9H-adenine (2) [37]. The nucleophilic addition reaction occurred only at the $\mathrm{N}-9$ atom. The hydroxyethyl compound (2) was chlorinated with $\mathrm{SOCl}_{2}$ to give intermediate 9-(2chloroethyl)-9H-adenine (3) [37]. Compounds 4-12 were synthesized by nucleophilic substitution of chlorine of (3) with the appropriate amine and piperazines.

6-Chloro-9-p-toluensulfonyl-9H-purine (14) was prepared from 6-chloropurine and $p$-toluensulfonyl chloride under SchottenBaumann conditions [38]. The amination of 14 with 1-(2hydroxyethyl)piperazine did not afford the desired product and compound 15 was formed (Scheme 2). This reaction sequence was not applicable for the synthesis of 6,9-disubstituted purine derivatives 28-34. Thus, 9-( $p$-toluene-sulfonyl)-6-substituted amino/ piperazinopurines (28-34) were first synthesized as shown in Scheme 3. Purines substituted at C-6 (15-27) were synthesized by nucleophilic substitution of the chlorine of 6-chloropurine (13) with the appropriate amine and piperazines in the presence of base. Compounds 15-27 were N-sulfonylated with complete regioselectivity applying the same set of reaction conditions as reported for the sulfonylation of adenine [39]. The sulfonylation reaction occurred only at the N-9 atom, without the concurrent $\mathrm{N}-7$ sulfonylation, as proved by the X-ray crystallographic analysis of the structure of compound $\mathbf{2 8}$ (Figs. 1 and 2).

9-Cyclopentyl-substituted purines 36, 37 [24] were synthesized via N-9 alkylation of $\mathbf{1 3}$ with cyclopentyl bromide, and by amination of 6-chloro-9-cyclopentylpurine 35 with 4-(4trifluoromethylphenyl)piperazine or 4-methylpiperidine (Scheme 4). The alkylation reaction occurred only at the N-9 atom. X-ray analysis [24] also confirmed the structure of compound 35.

Compounds 15, 17, 22, 24 could be alkylated with ethyl chloroacetate in DMF by first generating the anion with $\mathrm{NaH}$ (Scheme 5). This procedure yielded only one isolable compound which was identified as the expected 9-acetat substituted purines $(\mathbf{3 8}-\mathbf{4 1}) .{ }^{1} \mathrm{H}$ NMR Nuclear Overhauser Effect Spectroscopy (NOESY) also supported the structure of $\mathrm{N}-9$ regioisomer 41. The NOE interaction showed coupling between purine $\mathrm{N}-\mathrm{CH}_{2}$ and $\mathrm{H}-8$ protons, but no such interactions between any of the piperazine and purine $\mathrm{N}-\mathrm{CH}_{2}$ protons eliminate $\mathrm{N}-7$ acetylation. On the other hand, the<smiles>Cc1cnc2[nH]cnc2n1</smiles><smiles>Nc1ncnc2c1ncn2CCO</smiles>

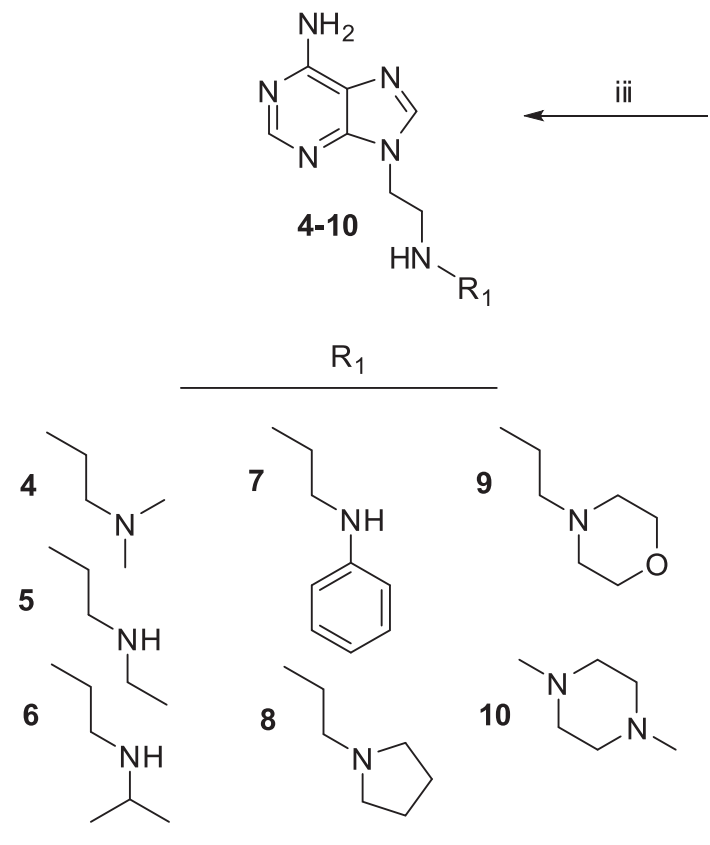<smiles>Nc1ncnc2c1ncn2CCCl</smiles><smiles>[R]CN1CCN(CCn2cnc3c(N)ncnc32)CC1</smiles>

Scheme 1. Reagents: i) Ethylene carbonate, $\mathrm{NaOH}, \mathrm{DMF}$; ii) $\mathrm{SOCl}_{2}$; iii) the appropriate amine, $\mathrm{EtOH}$; iv) the appropriate piperazine, EtOH. 


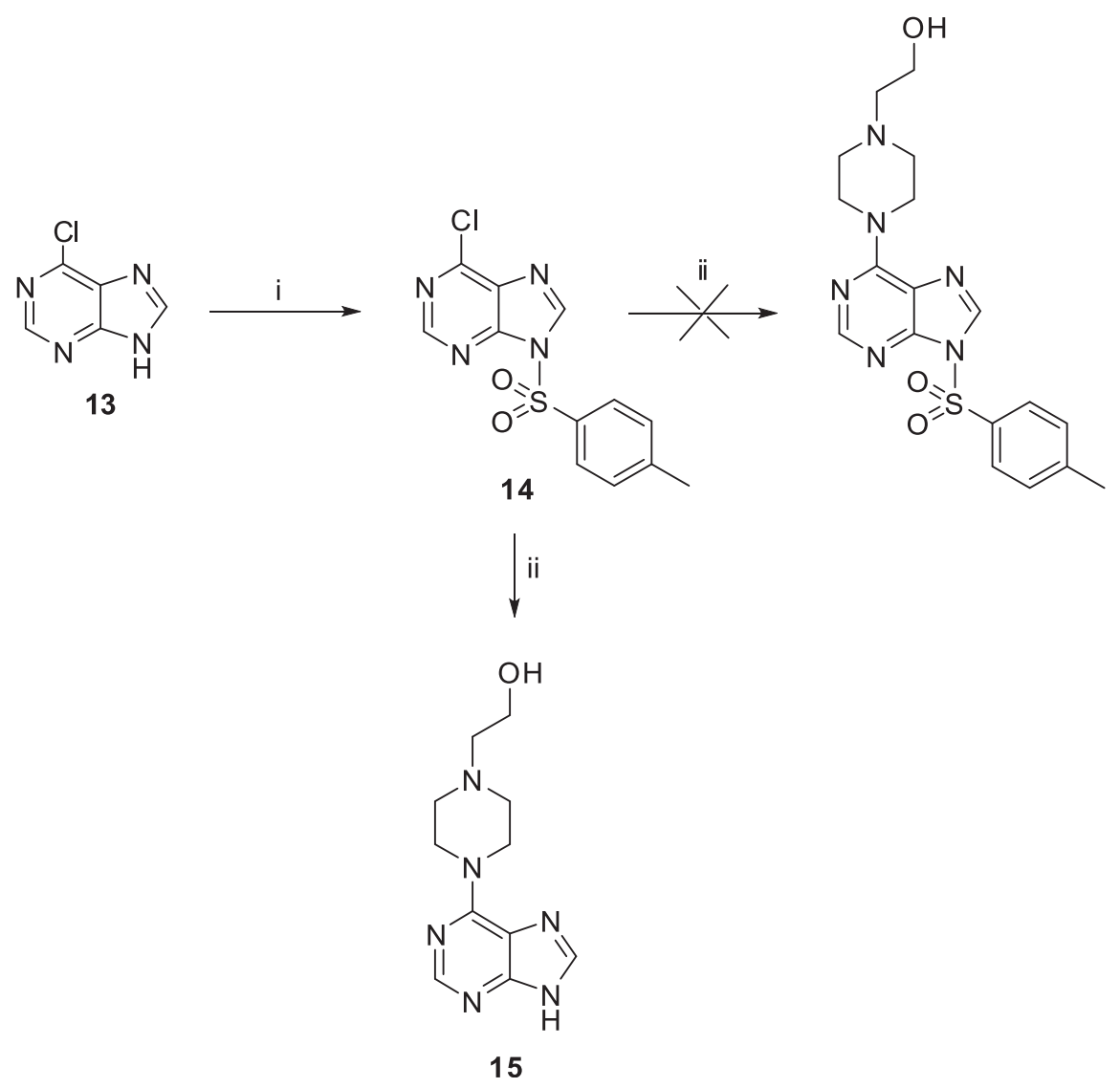

Scheme 2. Reagents: i) p-Toluensulfonyl chloride, $\mathrm{KOH}, \mathrm{H}_{2} \mathrm{O}$, acetone; ii) 1-(2-hydroxyethyl)piperazine, EtOH.

piperazine protons showed strong NOE interactions with phenyl ortho protons (Fig. 3).

\subsubsection{X-ray crystal structure analysis of compound $\mathbf{2 8}$}

Solid state packing of the compound $\mathbf{2 8}$ was investigated by using X-ray crystallography. The unit cell of $\mathbf{2 8}$ contains two crystallographically independent purine molecules named A and B in the asymmetric unit as shown in Fig. 1. The molecular structure with atom numbering scheme and the packing arrangement of the molecules are presented in Figs. 1 and 2. Details of crystallographic data and structure refinement parameters are given in Table 1.

The skeleton of the molecule consists of a purine moiety, a ptoluenesulfonyl moiety connected to $\mathrm{N} 9$ atom and the piperazine substituent (which contains trifluoromethyphenyl group) at C6 of the purine ring system. The purine moiety is almost planar and the dihedral angles between the mean planes of the pyrimidine and imidazole rings are $1.4(1)^{\circ}$ and $2.7(1)^{\circ}$ for molecule A and $\mathrm{B}$, respectively. The toluene ring joined to the purine moiety by a sulfonyl group is planar and forms an angle of $82.6(1)^{\circ}$ in molecule A [79.0 $(1)^{\circ}$ for B] with the average plane of the purine ring system. The conformation of the sulfonyl junction is characterized by the torsion angles $\mathrm{C} 4 \mathrm{~A}-\mathrm{N} 9 \mathrm{~A}-\mathrm{S} 1-\mathrm{C} 10 \mathrm{~A}=70.2(3)^{\circ}$ and $\mathrm{N} 9 \mathrm{~A}-\mathrm{S} 1-\mathrm{C} 10 \mathrm{~A}-\mathrm{C} 15 \mathrm{~A}=-86.8(3)^{\circ}$ [these values are $70.4(3)^{\circ}$ and $-84.5(3)^{\circ}$ for molecule B].

In (trifluoromethylphenyl)piperazine part of the compound $\mathbf{2 8}$, the piperazine ring adopts a chair conformation. The perpendicular distances of the two chair atoms in the 4. position (N1 $\mathrm{A}^{\prime}$ and $\mathrm{N} 4 \mathrm{~A}^{\prime}$ ) from the plane of the other four atoms of the six-membered piperazine ring are $0.585(3)$ and $-0.559(4) \AA$ for molecule A (for

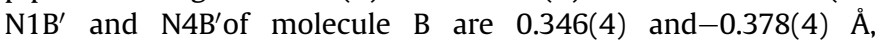

respectively). The dihedral angle between the best planes of the purine moiety and piperazine ring is $23.2(2)^{\circ}$ and $15.4(2)^{\circ}$ for $A$ and $\mathrm{B}$ molecules. The phenyl ring connected to the piperazine is also planar and makes an angle of $23.1(2)^{\circ}$ for A [16.2 (2) ${ }^{\circ}$ for B] with the plane defined by the four atoms of the piperazine ring.

In the structure, there is no classical intermolecular hydrogen bond. The packing diagram shows that the molecules are arranged in rows running parallel to the c-axis with the molecules in adjacent rows inverted.

\subsection{Biological evaluation and discussion}

The cytotoxicities of the compounds 4-12, 14-34, 36-41 were initially analysed on liver (Huh7), colon (HCT116) and breast (T47D) carcinoma cell lines (Table 2 ). The $\mathrm{IC}_{50}$ values after $72 \mathrm{~h}$ of treatment with each molecule were also calculated in comparison with the nucleobase analogue 5-fluorouracil (5-FU) and nucleoside analogues fludarabine, cladribine, pentostatine. 9-Substituted adenine derivatives (4-12) did not show any significant cytotoxic activity. By replacing the $\mathrm{C}-6 \mathrm{NH}_{2}$ group (4-12) with a $\mathrm{Cl}$ atom (14) resulted an increase in the cytotoxic activity against Huh7 $(20.8 \mu \mathrm{M})$, HCT116 $(22.8 \mu \mathrm{M})$, and T47D $(13.9 \mu \mathrm{M})$.

Among 6-substituted amino purine analogues, 6-(2cyclohexenylethyl)amino-9H-purine (26) and its 9-(p-toluene-sulfonyl) derivative (34) had promising $\mathrm{IC}_{50}$ against Huh7 $(14.2 \mu \mathrm{M}$ and $9.4 \mu \mathrm{M})$, HCT116 $(12.9 \mu \mathrm{M}$ and $8.7 \mu \mathrm{M})$, and T47D $(40.3 \mu \mathrm{M}$ and $34.5 \mu \mathrm{M})$ values upon $72 \mathrm{~h}$ of treatment. The substitution of $\mathrm{p}$ toluene-sulfonyl at $\mathrm{N}-9$ position enhanced the cytotoxic activity of the compound (34) and the $\mathrm{IC}_{50}$ values for $72 \mathrm{~h}$ of treatment were comparable to the well-known nucleobase analogue 5-FU (Table 2). 
<smiles>[R]C(C)(C)CCOc1ccc(C(F)(F)F)cc1</smiles><smiles>[R][X]CCN(CC)c1ncnc2[nH]cnc12</smiles><smiles>[R][X]C1CCN(c2ncnc3c2ncn3S(=O)(=O)c2ccc(C)cc2)CC1</smiles>

28 N<smiles>[R]C(C)c1ccc(C(F)(F)F)cc1</smiles>
29 C $\mathrm{CH}_{3}$<smiles>[13CH3]I</smiles><smiles>Clc1ncnc2[nH]cnc12</smiles>

13<smiles>[R]Nc1ncnc2[nH]cnc12</smiles>

19-27<smiles>[R]Nc1ncnc2c1ncn2S(=O)(=O)c1ccc(C)cc1</smiles><smiles>[R]C1CC1[13CH]</smiles>

31

32<smiles>CCc1ccc(OC)cc1CC</smiles>

33<smiles>CCCC1=CCCCC1</smiles>

34
22<smiles>CCc1cccc(C(F)(F)F)c1</smiles>

23<smiles>CCc1ccc(F)cc1F</smiles>

24<smiles>CCc1ccc(Cl)cc1Cl</smiles>

25<smiles>CCCNc1ccccc1</smiles>

26<smiles>CCCC1=CCCCC1</smiles>

27

nBuOH.

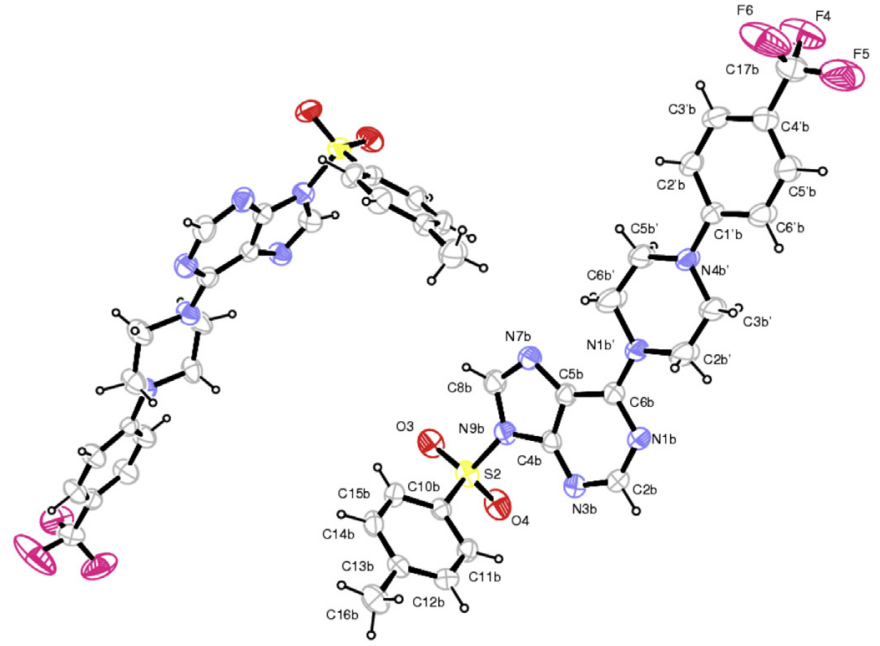

Fig. 1. Two molecules in the asymmetric unit of $\mathbf{2 8}$, showing the atom numbering scheme; displacement ellipsoids are drawn at the $30 \%$ probability level.
6-(4-Methylpiperidin-1-yl)-9-p-toluenesulfonyl-9H-purine (29) and its 9-cyclopentyl derivative (37) displayed very similar cytotoxicitiesas well. Therefore the effect of cyclopentyl substitution at N-9 position was not very significant (Table 2). Among the compounds synthesized in this study, analogues accommodating substituted benzyl at their C-6 position $(\mathbf{2 1}, \mathbf{2 2}, \mathbf{2 3}, \mathbf{2 4}, \mathbf{3 1}, \mathbf{3 2}, \mathbf{3 3}, \mathbf{3 8}$, and 39), 6-(2,4-dichlorobenzyl)amino-9-p-toluenesulfonyl-9H-purine (33) had noteworthy $\mathrm{IC}_{50}$ values against Huh7 $(26.9 \mu \mathrm{M})$, HCT116 $(28.1 \mu \mathrm{M})$, and T47D $(47.6 \mu \mathrm{M})$ is upon $72 \mathrm{~h}$ of treatment. When we evaluated the group of 9-acetate substituted purines (38-41), the 4-(4-trifluoromethylphenyl)piperazine substituted at C-6, the analogue 41, was the only 9-acetate derivative with an apparent $\mathrm{IC}_{50}$ (Table 2). The data presented in Table 2, indicated that the 4-(4-trifluoromethylphenyl)piperazine substitution was the most active group responsible for the cytotoxic activity.

Compounds 17, 28, and $\mathbf{3 6}$ have remarkable cytotoxic activities out of four purine analogues having 4-(4-trifluorophenyl)piperazine. When we compared their $\mathrm{IC}_{50}$ values upon for $72 \mathrm{~h}$ of treatment with the known cell growth inhibitors 5-FU, Fludarabine and Pentostatine, we observed that $\mathbf{1 7}$ which has no substitution at $\mathrm{N}-9$ 


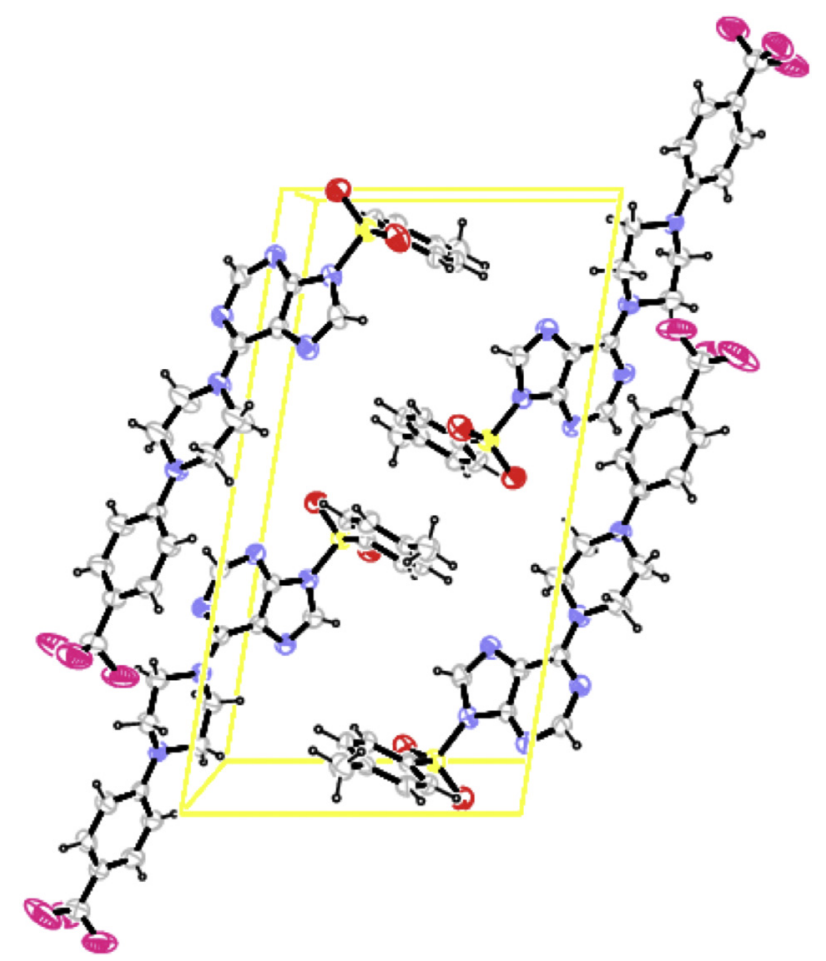

Fig. 2. The crystal packing in $\mathbf{2 8}$, showing the stacks of molecules running down the $c$ axis.

position and its 9-(p-toluene-sulfonyl)/9-cyclopentyl analogues $(\mathbf{2 8}, \mathbf{3 6})$ had showed more potent cytotoxicities in micromolar concentration ranges. Furthermore, $\mathbf{3 6}$ had a better cytotoxic activity than the known nucleoside drug, cladribine on Huh7 and HCT116 $(0.2,<0.1$ vs. 1.8 and $0.3 \mu \mathrm{M}$ for cladribine, Table 2). Therefore, these compounds $(\mathbf{1 7}, \mathbf{2 8}, \mathbf{3 6})$ were further analysed against a hepatocellular carcinoma (HCC) cell line panel consisting of Huh7, HepG2, Hep3B, PLC, SK-Hep1, Mahlavu, FOCUS, Snu182, Snu475cells. We observed the most significant cell growth inhibition in the presence of 9-cyclopentyl derivative, 36, with $\mathrm{IC}_{50}$ values of $0.2-9.6 \mu \mathrm{M}$ (Table 3, Fig. 4). The 9-(p-toluene-sulfonyl) analogue 28 was also very active $\mathrm{IC}_{50}$ values in range of $1.0-8.4 \mu \mathrm{M}$ against all tested cell lines upon $72 \mathrm{~h}$ of treatment.

\subsubsection{7, 28 and $\mathbf{3 6}$ induces nuclear condensation that is devoid of} apoptosis or necrosis

To further clarify the cytotoxic effect emerged in cancer cells treated with these three novel purine derivatives, we analysed these cells under florescence microscopy with Hoechst 33258 staining. After the observation of condensed apoptotic nuclei bearing horseshoe-like structures, (Fig. 5A) in the presence of 17, 28 and 36, we confirmed apoptosis through inspecting the expression levels of certain proteins known as apoptosis markers with western blot analysis. Staurosporine (STS) was used as positive control at its apoptosis-inducing dose. The poly (ADP-ribose) polymerase (PARP1 ), a $113 \mathrm{kDa}$ nuclear protein, known to be cleaved into fragments of $89 \mathrm{kDa}$ and $24 \mathrm{kDa}$ fragments during apoptosis, was analysed in the presence of the compounds. Mahlavu cells treated with 17, 28 and 36 at $\mathrm{IC}_{50}$ values for $72 \mathrm{~h}$ then were analysed for apoptosis by PARP1 cleavage assay via western blot. Compared to STS, the apoptotic fragment, cleaved-PARP ( $89 \mathrm{kDa}$ ) gave a weak signal while the $24 \mathrm{kDa}$ and necrosis dependent fragment $55 \mathrm{kDa}$ fragment were absent (Fig. 5B). In addition the expression levels of the antiapoptotic protein Bcl-2 and total Cytochrome-c levels were not altered in the presence of novel purine analogues (data not shown). Hence, the underlying mechanism of the cytotoxic action of these three purine analogues couldn't be considered as apoptosis or necrosis.

\subsubsection{Compounds 17, 28 and $\mathbf{3 6}$ had an effect on the ATP pool of} the cells comparable to their PARP cleavage activity

The growth inhibitory effects that we observed with these three purine derivatives were comparable to that of 5-fluorouracil (IC $50 \sim 10 \mu \mathrm{M}$, for $72 \mathrm{~h}$, Table 2 ). The differential (cell-line-dependent) cytotoxic activity of each molecule can be considered as an indicator of the specificity of these inhibitors against their target. They might interfere with the activity of certain kinases instead of acting as a multi-kinase inhibitor. Therefore, we evaluated the protein kinase inhibitory activity of these purine analogues. The

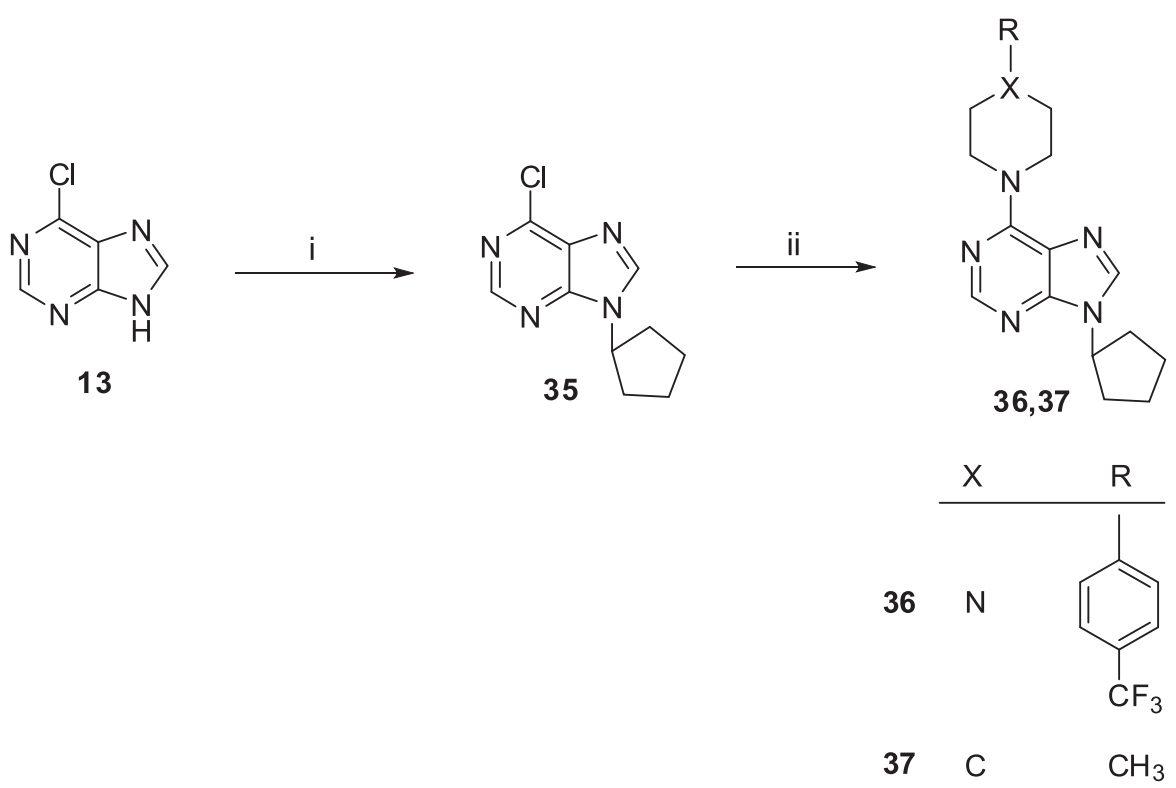

Scheme 4. Reagents: i) Cyclopentyl bromide, $\mathrm{K}_{2} \mathrm{CO}_{3}$, DMF; ii) 4-(4-trifluoromethylphenyl)piperazine or 4-methylpiperidine, Et ${ }_{3} \mathrm{~N}$, EtOH. 
<smiles></smiles>

22,24

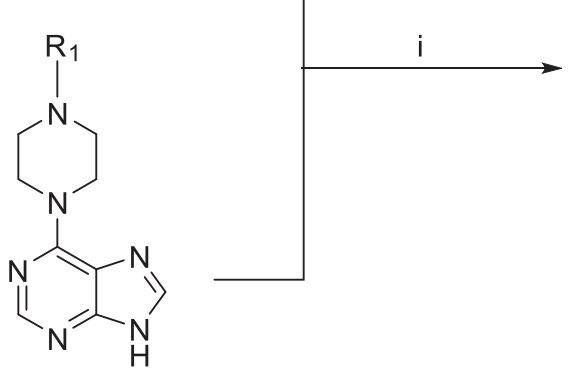

15,17<smiles>[R]Nc1ncnc2c1ncn2CC(=O)OCC</smiles><smiles>[R16]OC(=O)Cn1cnc2c(N3CCN([R])CC3)ncnc21</smiles>

38<smiles>CCc1cccc(C(F)(F)F)c1</smiles>

40<smiles>[R]C(C)(C)CCOc1ccc(C(F)(F)F)cc1</smiles>

Scheme 5. Reagents: i) $\mathrm{ClCH}_{2} \mathrm{COOEt}, \mathrm{NaH}(95 \%)$, DMF.

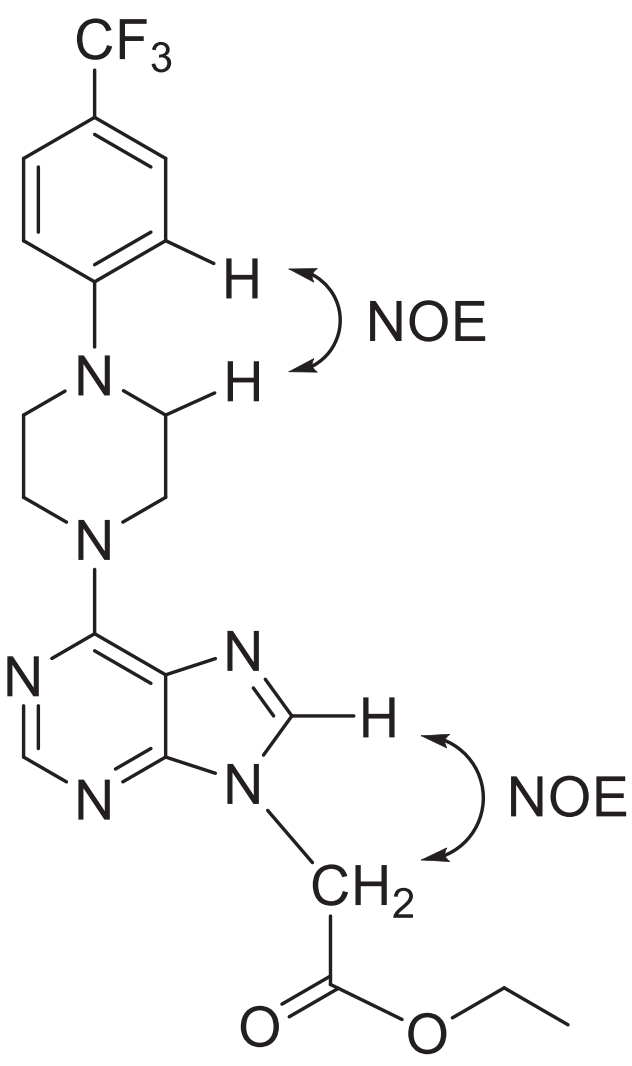

41

Fig. 3. Selected NOE interactions in structure of $\mathbf{4 1}$.

kinase assay based on the detection of the amount of ATP in the reaction mixture through bioluminescence was performed with Huh7 and Mahlavu cells (Fig. 6) [40,41]. The liver cancer cells incubated for $24 \mathrm{~h}$ with these new cytotoxic molecules and STS, a
Table 1

Crystal data and details of the structure determination of $\mathbf{2 8}$ compound.

\begin{tabular}{|c|c|}
\hline Crystal formula & $\mathrm{C}_{23} \mathrm{H}_{21} \mathrm{~N}_{6} \mathrm{O}_{2} \mathrm{~F}_{3} \mathrm{~S}$ \\
\hline Formula weight & 502.52 \\
\hline Crystal dimensions, $\left[\mathrm{mm}^{3}\right]$ & $0.710 \times 0.503 \times 0.310$ \\
\hline Temp, [ K] & $293(2)$ \\
\hline Wavelength, $[\AA]$ & 0.71073 \\
\hline Crystal system & Triclinic \\
\hline Space group; Z & $\mathrm{P}-1 ; 4$ \\
\hline$a,[\AA]$ & $10.1623(5)$ \\
\hline$b,[\AA]$ & $12.2302(6)$ \\
\hline$c,[\AA]$ & $18.8874(8)$ \\
\hline$\alpha,\left[^{\circ}\right]$ & $83.938(4)$ \\
\hline$\beta,\left[^{\circ}\right]$ & $80.750(4)$ \\
\hline$\Gamma,\left[^{\circ}\right]$ & $86.257(4)$ \\
\hline Volume & $2301.2(2)$ \\
\hline Range of $\theta,\left[^{\circ}\right]$ & 1.68 to 26.71 \\
\hline Abs. coefficient, $\left[\mathrm{mm}^{-1}\right]$ & 0.20 \\
\hline Absorption correction & Integrated \\
\hline$T_{\min }, T_{\max }$ & $0.9052,0.9626$ \\
\hline Reflections collected & 35,292 \\
\hline Reflections used in refinement & 9699 \\
\hline No. of refined parameters & 631 \\
\hline Refinement method & Full matrix \\
\hline$R / R_{w}$ values & $0.0701 / 0.1325$ \\
\hline GOF & 1.013 \\
\hline Final shift & 0.000 \\
\hline$(\Delta \rho)_{\min },(\Delta \rho)_{\max }\left(\mathrm{e} \AA^{-3}\right)$ & $0.47,-0.39$ \\
\hline
\end{tabular}

multi-kinase inhibitor used as a positive control. The decrease in intrinsic cellular ATP consumption, in other words increase in the light intensity, in the presence of these three purine analogues was more apparent in Huh7 cells compared to Mahlavu cells. Interestingly, the comparative cleaved-PARP levels in Mahlavu cells upon 17, 28, 36 and STS treatment was very similar to the comparative kinase inhibitory potential of these three novel purine analogues and STS in Mahlavu cells (Figs. 5B and 6). Based on the results we obtained, the newly synthesized purine derivatives, 17, 28 and $\mathbf{3 6}$ can be considered as putative protein kinase inhibitors, which must be further analysed at the molecular level.

$\mathrm{N}^{6}$-(4-Trifluoromethylphenyl)piperazine derivative, compound 36, displayed the greatest cytotoxic activity with $\mathrm{IC}_{50}$ less than $1 \mu \mathrm{M}$ 
Table 2

In vitro cytotoxicity of compounds $\mathbf{4 - 1 2 , 1 4 - 3 4 , 3 6 - 4 1}$ on different human cancer cell lines.<smiles>[R]c1ncnc2c1ncn2[R1]</smiles>

\begin{tabular}{|c|c|c|c|c|c|}
\hline \multirow[t]{2}{*}{ Compound } & \multirow[t]{2}{*}{$R$} & \multirow[t]{2}{*}{$\bar{R}$} & \multicolumn{3}{|c|}{ Cancer cell line, $\mathrm{IC}_{50}(\mu \mathrm{M})^{\mathrm{a}}$} \\
\hline & & & Huh7 & HCT116 & T47D \\
\hline 4 & $\mathrm{NH}_{2}$ & & $\mathrm{NI}$ & $\mathrm{NI}$ & $\mathrm{NI}$ \\
\hline 5 & $\mathrm{NH}_{2}$ & & $\mathrm{NI}$ & $\mathrm{NI}$ & $\mathrm{NI}$ \\
\hline 6 & $\mathrm{NH}_{2}$ & & $\mathrm{NI}$ & $\mathrm{NI}$ & $\mathrm{NI}$ \\
\hline 7 & $\mathrm{NH}_{2}$ & & NI & $\mathrm{NI}$ & $\mathrm{NI}$ \\
\hline 8 & $\mathrm{NH}_{2}$ & & $\mathrm{NI}$ & $\mathrm{NI}$ & $\mathrm{NI}$ \\
\hline 9 & $\mathrm{NH}_{2}$ & & $\mathrm{NI}$ & $\mathrm{NI}$ & $\mathrm{NI}$ \\
\hline 10 & $\mathrm{NH}_{2}$ & & $\mathrm{NI}$ & $\mathrm{NI}$ & $\mathrm{NI}$ \\
\hline 11 & $\mathrm{NH}_{2}$ & & $\mathrm{NI}$ & $\mathrm{NI}$ & $\mathrm{NI}$ \\
\hline 12 & $\mathrm{NH}_{2}$ & & $\mathrm{NI}$ & $\mathrm{NI}$ & $\mathrm{NI}$ \\
\hline 14 & $\mathrm{Cl}$ & & 20.8 & 22.8 & 13.9 \\
\hline 15 & 1 & $\mathrm{H}$ & NI & $\mathrm{NI}$ & $\mathrm{NI}$ \\
\hline
\end{tabular}


Table 2 (continued)

\begin{tabular}{|c|c|c|c|c|c|}
\hline \multirow[t]{2}{*}{ Compound } & \multirow[t]{2}{*}{$R$} & \multirow[t]{2}{*}{$R_{1}$} & \multicolumn{3}{|c|}{ Cancer cell line, $\mathrm{IC}_{50}(\mu \mathrm{M})^{\mathrm{a}}$} \\
\hline & & & Huh7 & НCT116 & T47D \\
\hline 16 & & $\mathrm{H}$ & $\mathrm{NI}$ & $\mathrm{NI}$ & $\mathrm{NI}$ \\
\hline 17 & & $\mathrm{H}$ & 3.2 & 5.1 & 39.4 \\
\hline 18 & & $\mathrm{H}$ & $\mathrm{NI}$ & NI & $\mathrm{NI}$ \\
\hline 19 & & $\mathrm{H}$ & NI & NI & $\mathrm{NI}$ \\
\hline 20 & & $\mathrm{H}$ & $\mathrm{NI}$ & NI & $\mathrm{NI}$ \\
\hline 21 & & $\mathrm{H}$ & NI & 86.6 & $\mathrm{NI}$ \\
\hline 22 & & $\mathrm{H}$ & 68.3 & 102.1 & $\mathrm{NI}$ \\
\hline 23 & & $\mathrm{H}$ & NI & $\mathrm{NI}$ & $\mathrm{NI}$ \\
\hline 24 & & $\mathrm{H}$ & $\mathrm{NI}$ & NI & 146.8 \\
\hline 25 & & $\mathrm{H}$ & $\mathrm{NI}$ & 131.6 & $\mathrm{NI}$ \\
\hline 26 & & $\mathrm{H}$ & 14.2 & 12.9 & 40.3 \\
\hline
\end{tabular}


Table 2 (continued)

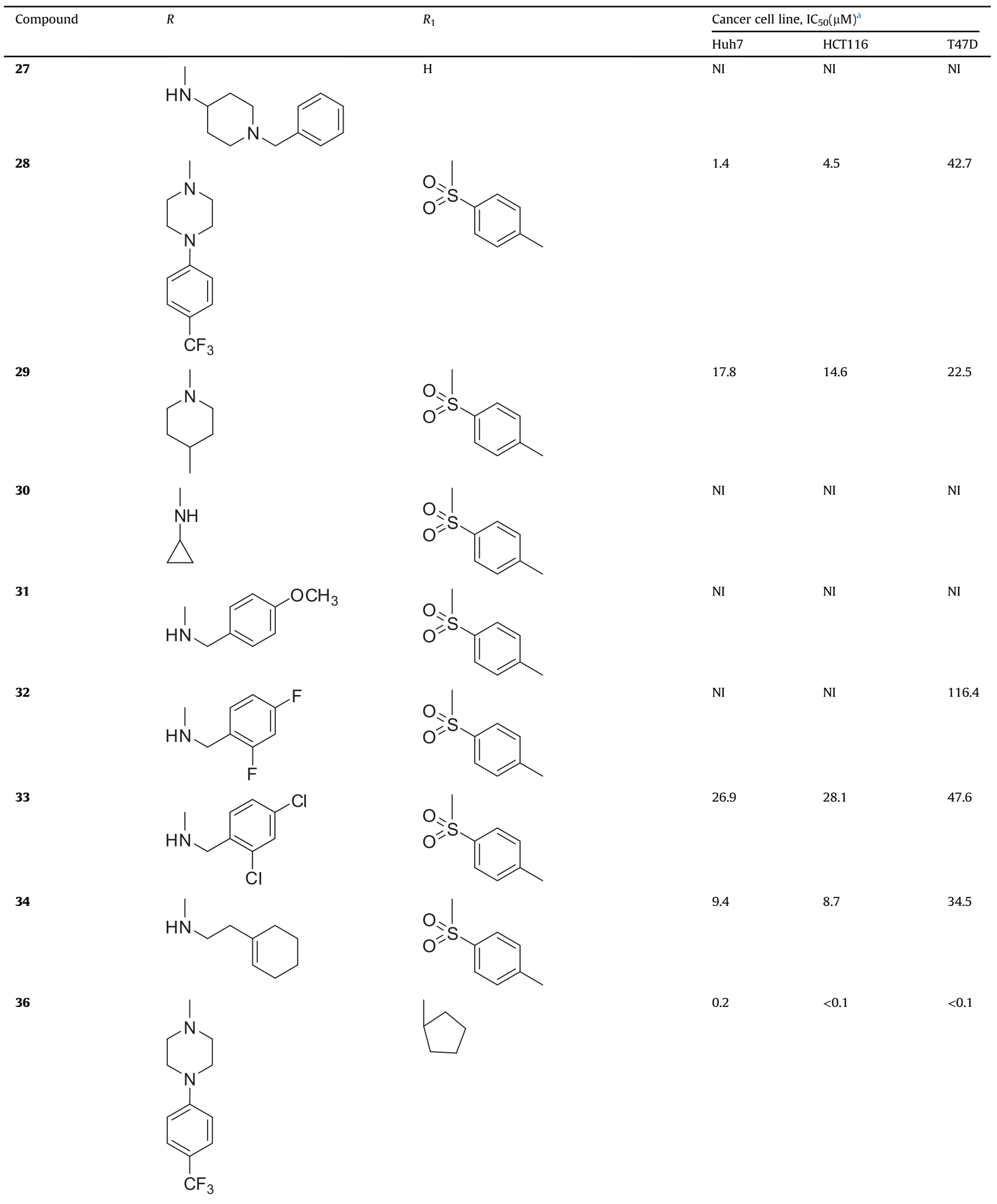


Table 2 (continued)

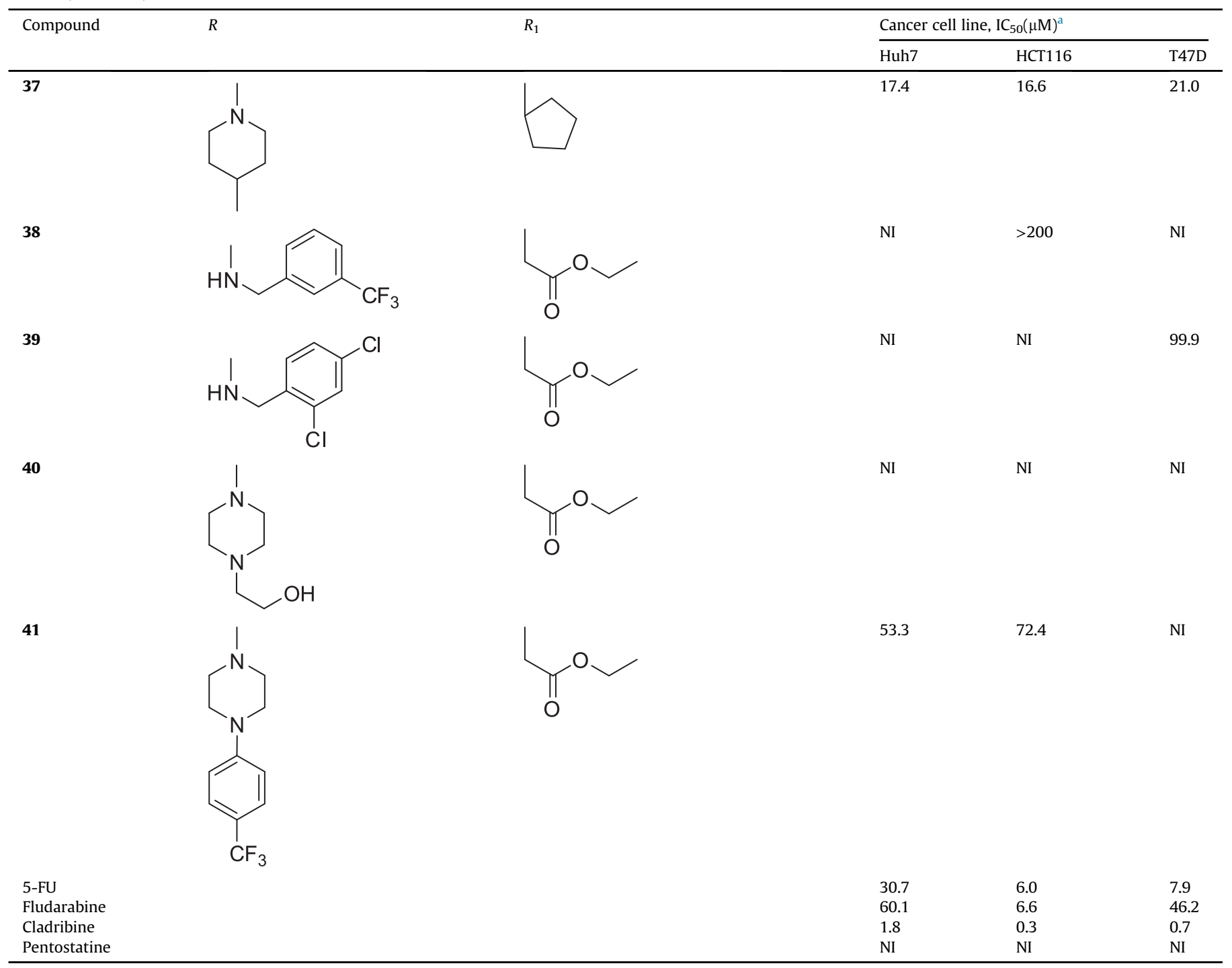

NI: no inhibition.

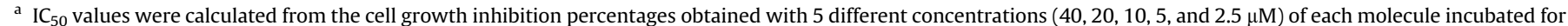
$72 \mathrm{~h}$.

on all liver cancer cell lines tested, except PLC $(6.4 \pm 1.19 \mu \mathrm{M})$ and Snu182 $(9.8 \pm 2.48 \mu \mathrm{M})$ (Table 3$)$. When we compare their IC 50 values with 5-FU, we observed that the newly synthesized compound $\mathbf{3 6}$ had comparable and even better. Considering its cytotoxic activity which is even better than 5-FU, we further analysed the cellular activity of compound $\mathbf{3 6}$ on liver cancer cell lines, Huh7, HepG2, Mahlavu and FOCUS. Time-dependent cytotoxicities and the $\mathrm{IC}_{50}$ values (for 24, 48, $72 \mathrm{~h}$ ) of $\mathbf{3 6}$ were given in Fig. 7 and Table 4 respectively. Although the purine analogue, 36 inducedcytotoxicity was similar for all the cell lines at $72 \mathrm{~h}$, the $24 \mathrm{~h}$ of incubation, this molecule was not significantly active on Mahlavu and FOCUS cells. The time dependent cytotoxicity data of $\mathbf{3 6}$ demonstrated that this novel purine analogue induces cell-line-dependent "short term" cytotoxicity; while, the "long term" 36 responses had a differential activity on the selected liver cancer cells.

\subsubsection{Real-time cellular response of hepatocellular carcinoma cells with compound $\mathbf{3 6}$ treatment}

Real-time Cell Electronic Sensing (RT-CES) system has been used to evaluate the compound $\mathbf{3 6}$ mediated cytotoxicity on Huh7,
HepG2, and Mahlavu liver cancer cells in triplicate. The real-time dynamic monitoring of the electrode impedance indicates a Cell Index $(\mathrm{CI})$ correlated with cell growth. Compound $\mathbf{3 6}$ triggered a time- and dose-dependent decrease in cell growth indexes in all HCC cells (Fig. 8). The percent cytotoxicity, clearly demonstrates the potent inhibitory action of compound $\mathbf{3 6}$ depending on the concentrations employed $(40-2.5 \mu \mathrm{M})$. The PTEN protein deficient cell line Mahlavu was affected least by $\mathbf{3 6}$. Mahlavu cells have hyperactive PI3K/Akt pathway due to PTEN deficiency [42]. Since we hypothesized that this compound $\mathbf{3 6}$ might be a putative kinaseprotein interfering molecule (Fig. 6), the requirement of higher concentrations of purine analogue $\mathbf{3 6}$ to create cytotoxicity on kinase pathway hyperactive Mahlavu cells were rational.

\subsubsection{The novel, purine analogue 36 induces cellular senescence}

Both the time-dependent SRB assays and the real-time cellular response of liver cancer cells with compound $\mathbf{3 6}$ indicated that the cytotoxic activity of $\mathbf{3 6}$ is a "long-term" arising response. This fact indicates that the cell death type related to the molecular action of $\mathbf{3 6}$ might be senescence. In order to identify this possibility, we used 
Table 3

IC50 values of 17, $\mathbf{2 8}$ and $\mathbf{3 6}$ against HCC cell line panel: The liver cancer cells were incubated with each analogue for $72 \mathrm{~h}$ and the IC50 values are in $\mu \mathrm{M}$ range. NI stands for "no inhibition".

\begin{tabular}{|c|c|c|c|}
\hline $\mathrm{R}$ & \multicolumn{3}{|l|}{$\mathrm{R}$} \\
\hline $\mathrm{N}_{\mathrm{R}}$ & & . & \\
\hline & \multicolumn{3}{|l|}{$\mathrm{R}_{1}$} \\
\hline & 17 & 28 & 36 \\
\hline & $-\mathrm{H}$ & & \\
\hline HCC cell line: & \multicolumn{3}{|c|}{ IC50 values $(\mu \mathrm{M})$} \\
\hline Huh7 & $3.2 \pm 0.07$ & $1.4 \pm 0.01$ & $0.2 \pm 0.04$ \\
\hline HepG2 & $3.7 \pm 0.25$ & $1.2 \pm 0.2$ & $0.3 \pm 0.01$ \\
\hline Нер3в & $6.7 \pm 0.20$ & $2.9 \pm 0.63$ & $0.8 \pm 0.45$ \\
\hline PLC & $10.5 \pm 0.40$ & $3.7 \pm 0.46$ & $6.4 \pm 1.19$ \\
\hline SK-Hep1 & $4.9 \pm 0.29$ & $1.7 \pm 0.17$ & $0.2 \pm 0.01$ \\
\hline Mahlavu & $2.3 \pm 0.06$ & $1.0 \pm 0.09$ & $0.1 \pm 0.01$ \\
\hline FOCUS & $2.9 \pm 0.27$ & $1.0 \pm 0.02$ & $0.2 \pm 0.06$ \\
\hline Snu182 & $55.4 \pm 4.7$ & $8.4 \pm 0.26$ & $9.6 \pm 2.48$ \\
\hline Snu475 & $9.6 \pm 0.20$ & $5.4 \pm 0.49$ & $\mathrm{NI}$ \\
\hline
\end{tabular}

Senescence associated- $\beta$-galactosidase and BrdU incorporation assays in parallel. Huh7 cells plated with cover slips to 6-well plates were incubated with $\mathrm{IC}_{50}$ and $\mathrm{IC}_{100}$ values (Table 2 ) in the presence of 36, doxorubicin and DMSO-controls for 3 days and 6 days. Doxorubicin was used as a positive control at its senescence-inducing dose (25 ng/ml) [43]. BrdU (30 $\mu \mathrm{M})$ was administered to test its incorporation into cellular DNA of Huh7 cells $24 \mathrm{~h}$ prior to the end of 3 days and 6 days long incubations. Compound 36 treated Huh7 cells showed senescence associated morphology (Large blue stained cells (in web version)) and also the blue-stained (SA- $\beta$-gal positive) cells were negative for BrdU incorporation, whereas DMSO-only applied Huh7 cells were BrdU positive (Small blue cells), proliferating cells (Fig. 9).

\section{Conclusion}

A series of 9-substituted adenines (4-12), 6-substituted purines (15-27) and 6,9-disubstituted purine analogues (28-34, 36-41) were synthesized and their anti-cancer activities were identified. Among these 36 compounds, $\mathrm{N}^{6}$-(4-trifluoromethylphenyl)piperazine derivative (17) without any substitution at N-9 position and its 9-(p-toluene-sulfonyl)/9-cyclopentyl analogues $(\mathbf{2 8}, \mathbf{3 6})$ were further analysed for their activity against a hepatocellular carcinoma (HCC) panel due to their promising cytotoxicities. Despite the observed nuclear condensation and DNA fragmentation features of apoptosis, decrease in Bcl-2 and Cyt-c protein expression levels and cleaved-PARP protein levels were not prominent in the presence of 17, 28 and 36. Compound 36, which was designed as a putative kinase inhibitor, displayed the best bioactivity with $\mathrm{IC}_{50}$ valuesless than $1 \mu \mathrm{M}$ on almost all liver cancer cell lines tested; therefore, the further analysis were carried on with $\mathbf{3 6}$. The long term ( $72 \mathrm{~h}$ ) drug response of liver cancer cells to the novel, candidate-chemotherapeutic agent,

A)

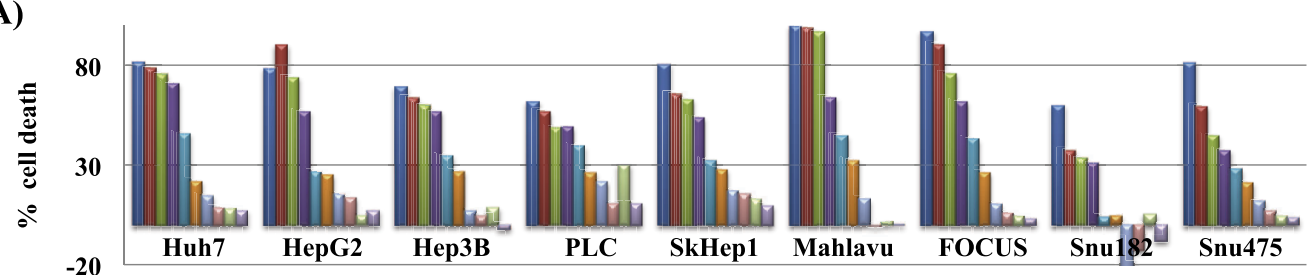

B)

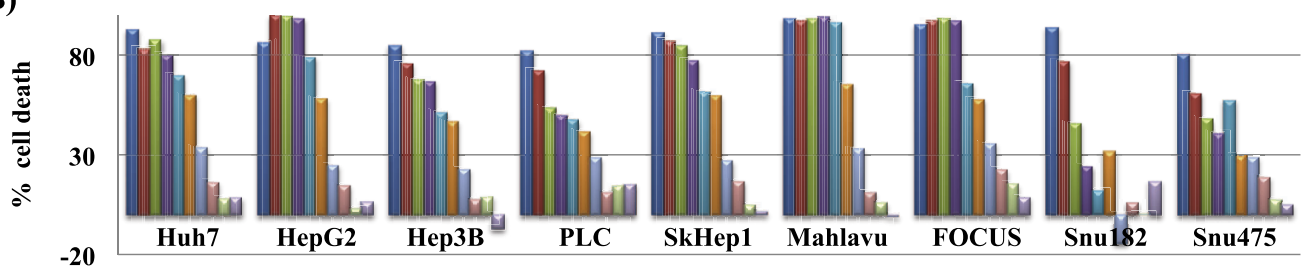

C)

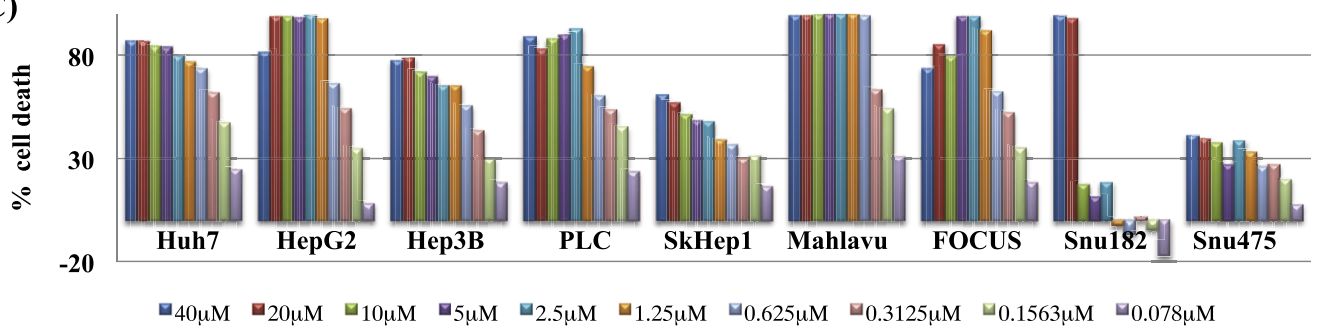

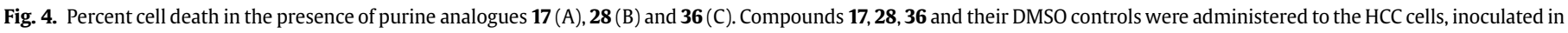
96-well plates, with ten different concentrations for $72 \mathrm{~h}$. Following the SRB assay, the cell death percentages were calculated in comparison to DMSO-only treated wells. 
A)

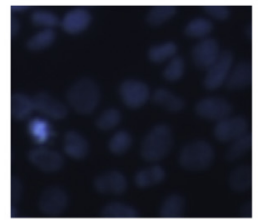

DMSO

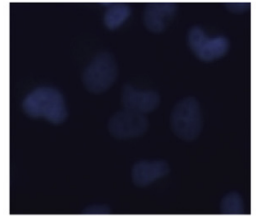

DMSO

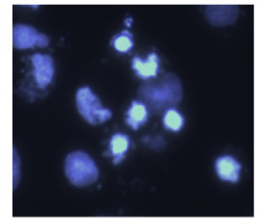

CPT

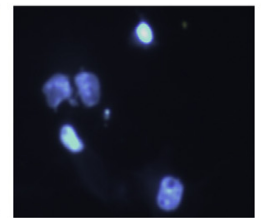

CPT

\section{Huh7}

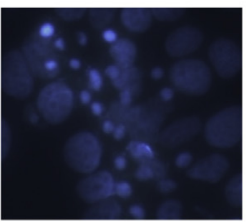

17

\section{FOCUS}

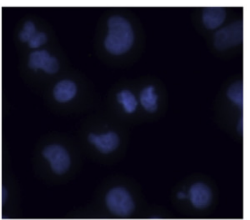

17

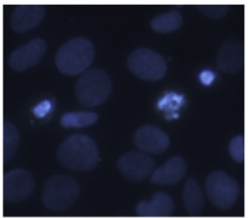

28

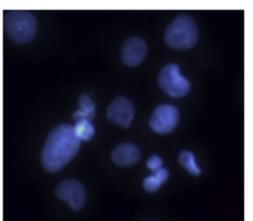

28

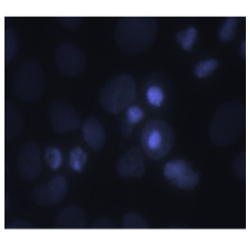

36

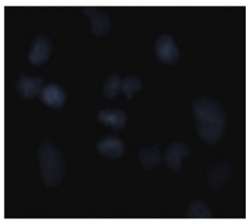

36

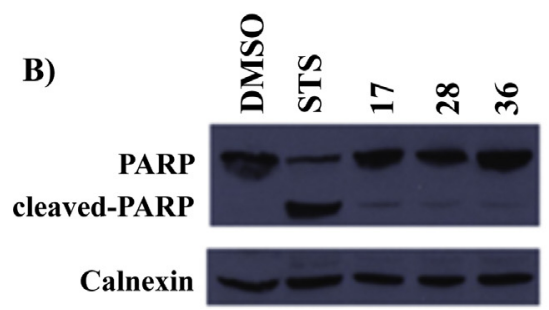

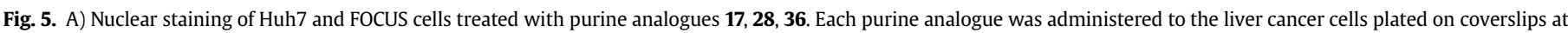

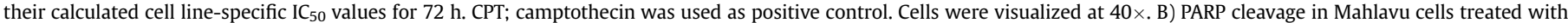
purine analogues 17, 28, 36 at theirIC50 values for 72 h. STS; staurosporine was used as positive control. Calnexin was used as equal loading.

substituted purine analogue $\mathbf{3 6}$, was considerably more effective comparing to short term ( $24 \mathrm{~h}$ ) drug response.

The results this study, indicated that the compound $\mathbf{3 6}$ initiates senescence associated cell death in a dose- and time-dependent manner which has been described as a therapeutic mode of action for small molecule inhibitors recently [44]. Although there had been reported nucleoside analogues inducing senescence such as toyocamycin and decitabine, it is rare to identify purine analogues as a senescence-inducing drug candidate [30,31].

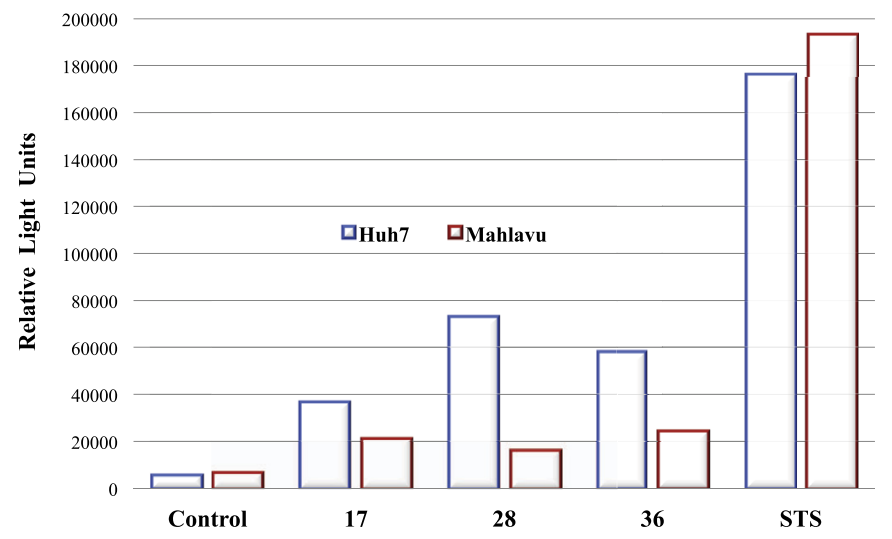

Fig. 6. Kinase inhibitory potential of purine analogues 17,28 and 36 . The relative light units measured after the kinase assay was performed with $20 \mu \mathrm{g}$ protein from Huh7 and Mahlavu cells treated with the $\mathbf{1 7}, \mathbf{2 8}$ and $\mathbf{3 6}$ at their given $\mathrm{IC}_{50}$ values (for $72 \mathrm{~h}$ ). STS; staurosporine $(0.25 \mu \mathrm{M})$ was used as positive control.

\section{Experimental section}

\subsection{Chemistry}

Melting points were recorded with a capillary melting point apparatus (Electrothermal 9100) and are uncorrected. NMR spectra were recorded on a VARIAN Mercury 400 FT-NMR spectrometer (400 for ${ }^{1} \mathrm{H}, 100.6 \mathrm{MHz}$ for ${ }^{13} \mathrm{C}$ ). TMS was used as internal standard for the ${ }^{1} \mathrm{H}$ and ${ }^{13} \mathrm{C}$ NMR spectra; values are given in $\delta(\mathrm{ppm})$ and $J$ values are in $\mathrm{Hz}$. High resolution mass spectra data (HRMS) were collected in-house using a Waters LCT Premier XE Mass Spectrometer (high sensitivity orthogonal acceleration time-of-flight instrument) operating in ESI $(+)$ method, also coupled with an AQUITY Ultra Performance Liquid Chromatography system (Waters Corporation, Milford, MA, USA). All compounds have a purity $>95 \%$ as measured by these LC-MS analyses. Elemental analyses $(\mathrm{C}, \mathrm{H}, \mathrm{N})$ were determined on a Leco CHNS 932 instrument and gave values within $\pm 0.4 \%$ of the theoretical values. Column chromatography was accomplished on silica gel 60 (40-63 mm particle size). For the $\mathrm{HCl}$ salts of the synthesized compounds, the free bases were dissolved in $\mathrm{EtOH} / \mathrm{MeOH}$ and a few drops of conc. $\mathrm{HCl}$ was added. The chemical reagents used in synthesis were purchased from E. Merck, Fluka, Sigma and Aldrich.

\subsubsection{9-(2'-Hydroxyethyl)-9H-adenine (2)}

A solution of adenine (1) $(0.56 \mathrm{~g}, 2.07 \mathrm{mmol})$, ethylene carbonate $(0.4 \mathrm{~g}, 4.54 \mathrm{mmol})$ and a trace of $\mathrm{NaOH}$ in $\mathrm{DMF}(10 \mathrm{ml})$ was heated at reflux for $4 \mathrm{~h}$. After evaporation of solvent under reduced pressure, the crude product was recrystallized from EtOH. Yield: 78\%, mp: 239-240 ${ }^{\circ} \mathrm{C}$ (Lit. [37] 238.3-240.4 ${ }^{\circ} \mathrm{C}$ ). ${ }^{1} \mathrm{H}$ NMR (DMSO$\left.\mathrm{d}_{6}\right) \delta 3.75\left(\mathrm{q}, 2 \mathrm{H}, \mathrm{CH}_{2} \mathrm{OH}\right), 4.18\left(\mathrm{t}, 2 \mathrm{H}, \mathrm{CH}_{2} \mathrm{~N}\right), 4.97(\mathrm{t}, 1 \mathrm{H}, \mathrm{OH}), 7.12(\mathrm{br}$ $\left.\mathrm{s}, 2 \mathrm{H}, \mathrm{NH}_{2}\right), 8.06(\mathrm{~s}, 1 \mathrm{H}, \mathrm{H}-8), 8.13(\mathrm{~s}, 1 \mathrm{H}, \mathrm{H}-2) .{ }^{13} \mathrm{C}$ NMR $\left(\mathrm{DMSO}^{-\mathrm{d}_{6}}\right)$ 


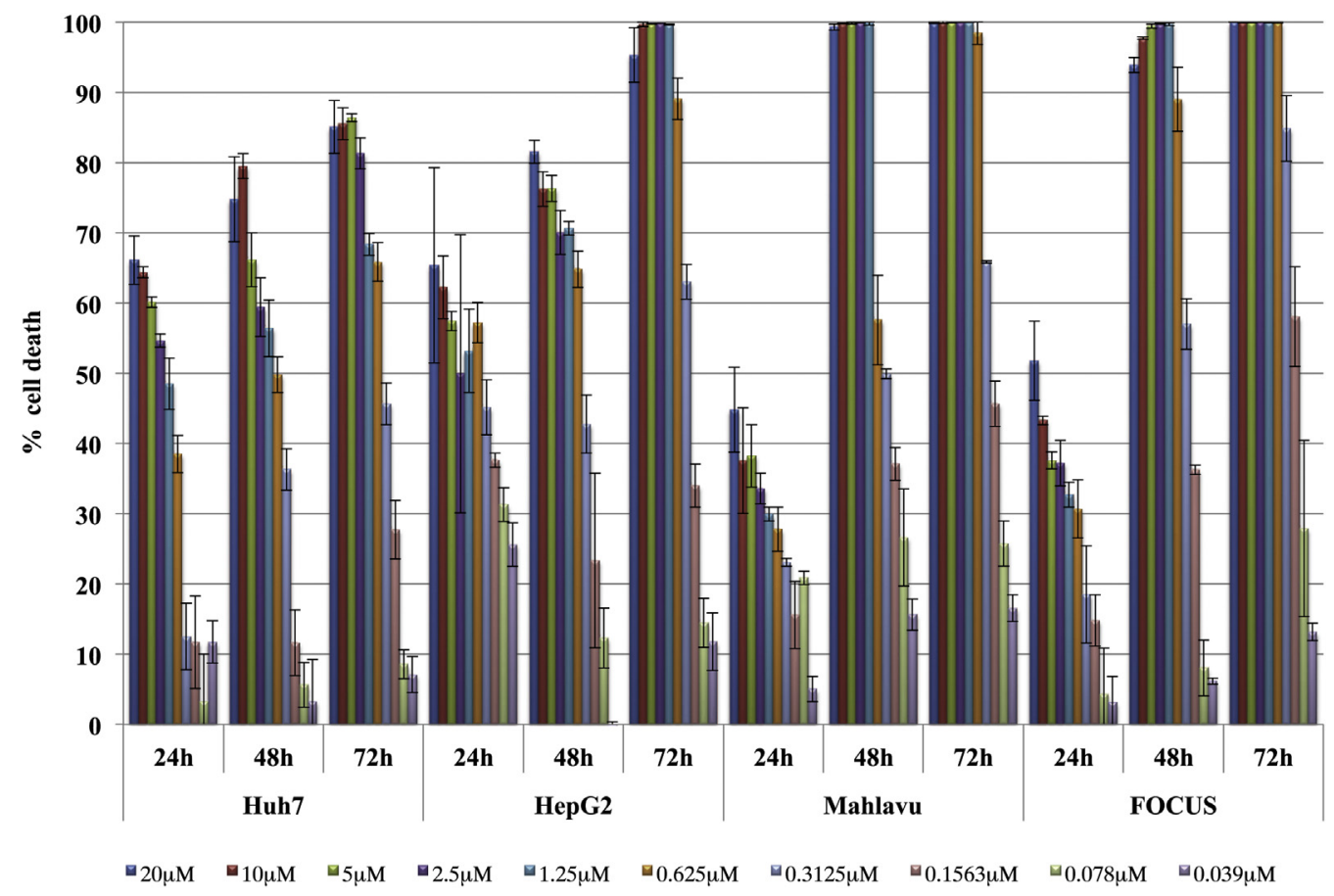

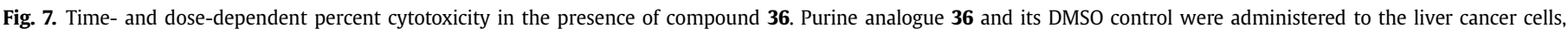

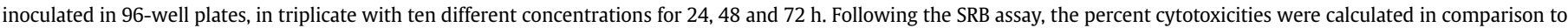
DMSO-only treated wells.

$\delta 45.71\left(\mathrm{CH}_{2} \mathrm{~N}\right), 59.25\left(\mathrm{CH}_{2} \mathrm{OH}\right), 118.71(\mathrm{C}-5), 141.31(\mathrm{C}-8), 149.54(\mathrm{C}-$ 6), 152.24 (C-2), 155.91 (C-4). MS (ESI+) $m / z 180.0(\mathrm{M}+\mathrm{H})(100 \%)$.

\subsubsection{9-(2'-Chloroethyl)-9H-adenine (3)}

A mixture of 9-(2'-hydroxyethyl)-9H-adenine (2) (0.19 g, $1.06 \mathrm{mmol})$ and $\mathrm{SOCl}_{2}(7 \mathrm{ml})$ was heated at reflux for $2 \mathrm{~h}$. Excess $\mathrm{SOCl}_{2}$ was removed in vacuo and the crude product was recrystallized from EtOH. Yield: 72\%, mp: 204-206 ${ }^{\circ} \mathrm{C}$ (Lit. [43] $\left.204.4-205.6{ }^{\circ} \mathrm{C}\right) .{ }^{1} \mathrm{H}$ NMR (DMSO-d 6$) \delta 4.11\left(\mathrm{t}, 2 \mathrm{H}, \mathrm{CH}_{2} \mathrm{~N}\right), 4.63(\mathrm{t}$, $2 \mathrm{H}, \mathrm{CH}_{2} \mathrm{Cl}$ ), $8.54(\mathrm{~s}, 1 \mathrm{H}, \mathrm{H}-8), 8.57$ (s, $\left.1 \mathrm{H}, \mathrm{H}-2\right), 9.20$ (br s, $2 \mathrm{H}$, $\left.\mathrm{NH}_{2}\right) \cdot{ }^{13} \mathrm{C}$ NMR (DMSO-d 6$) \delta 42.93\left(\mathrm{CH}_{2} \mathrm{Cl}\right), 45.37\left(\mathrm{CH}_{2} \mathrm{~N}\right), 117.96(\mathrm{C}-$ 5), 144.06 (C-8), 145.25 (C-6), $148.62(\mathrm{C}-2), 150.57$ (C-4). MS (ESI+) $\mathrm{m} / z 198.2(\mathrm{M}+\mathrm{H})(100 \%), 200.3(\mathrm{M}+\mathrm{H}+2)(34 \%)$.

\subsubsection{General procedure for the synthesis of compounds 4-12}

To a suspension of 9-(2'-chloroethyl)-9H-adenine (3) $(0.5 \mathrm{mmol})$ in absolute EtOH $(5 \mathrm{ml})$ was added the appropriate amine/piperazine (excess) and the mixture was refluxed for $8-15 \mathrm{~h}$. The reaction mixture was concentrated in vacuo and the residue was purified by column chromatography.

4.1.3.1. 9-[2-[2'-(N,N-Dimethylamino)ethyl]amino]ethyl-9H-adenine $\mathrm{HCl}$ (4). The compound was prepared from 3 and $\mathrm{N}, \mathrm{N}$ -

\section{Table 4}

Time-dependent $\mathrm{IC}_{50}$ values of $\mathbf{3 6}$. Compound $\mathbf{3 6}$ was applied in triplicates to liver cancer cells inoculated into 96-well plates and incubated for 24, 48 and $72 \mathrm{~h}$. The $\mathrm{IC}_{50}$ values are in $\mu \mathrm{M}$ range.

\begin{tabular}{lcll}
\hline & \multicolumn{2}{l}{} & \\
\cline { 2 - 4 } & $24 \mathrm{~h}$ & $48 \mathrm{~h}$ & $72 \mathrm{~h}$ \\
\hline Huh7 & $2.7 \pm 0.31$ & $1.4 \pm 0.30$ & $0.6 \pm 0.04$ \\
HepG2 & $1.2 \pm 0.25$ & $0.8 \pm 0.04$ & $0.2 \pm 0.04$ \\
Mahlavu & $50.1 \pm 11.66$ & $0.3 \pm 0.03$ & $0.2 \pm 0.01$ \\
FOCUS & $16.7 \pm 4.1$ & $0.3 \pm 0.02$ & $0.1 \pm 0.04$ \\
\hline
\end{tabular}

dimethylethylenediamine according to general procedure and was purified by column chromatography with EtOAc/MeOH/NH (10:5:0.4) as eluent. Yield: $48 \%$, mp: $225-228{ }^{\circ} \mathrm{C} .{ }^{1} \mathrm{H}$ NMR (DMSO$\left.\mathrm{d}_{6}\right) \delta 2.88\left(\mathrm{~s}, 6 \mathrm{H}, \mathrm{N}\left(\mathrm{CH}_{3}\right)_{2}\right), 3.41-3.55\left(\mathrm{~m}, 8 \mathrm{H}, \mathrm{CH}_{2}\right), 3.67(\mathrm{t}, 2 \mathrm{H}$, Purine-N-CH $\mathrm{CH}_{2}, 8.31$ (s, $\left.1 \mathrm{H}, \mathrm{H}-8\right), 8.39(\mathrm{~s}, 1 \mathrm{H}, \mathrm{H}-2) .{ }^{13} \mathrm{C}$ NMR (DMSO$\left.\mathrm{d}_{6}\right) \delta 34.36\left(\mathrm{~N}-\mathrm{CH}_{3}\right), 41.79,42.99,46.38\left(\mathrm{CH}_{2}-\mathrm{N}\right), 52.53\left(\mathrm{CH}_{2}-\mathrm{pu}-\right.$ rine N), 118.97 (C-5), 144.54 (C-8), 145.86 (C-6), 149.75 (C-2), 151.21 (C-4). HRMS (ESI+) $\mathrm{m} / z$ calcd for $\mathrm{C}_{11} \mathrm{H}_{20} \mathrm{~N}_{7}(\mathrm{M}+\mathrm{H})^{+}$250.1780, found 250.1781. Anal. Calcd for $\mathrm{C}_{11} \mathrm{H}_{19} \mathrm{~N}_{7} .4 \mathrm{HCl} .0 .2 \mathrm{C}_{2} \mathrm{H}_{5} \mathrm{OH} .2 .0 \mathrm{H}_{2} \mathrm{O}$ : C, 31.09; H, 6.45; N, 22.26. Found C, 31.30; H, 6.78; N, 22.24.

4.1.3.2. 9-[2-[2'-(N-Ethylamino)ethyl]amino]ethyl-9H-adenine $\mathrm{HCl}$ (5). The compound was prepared from 3 and N-ethylethylenediamine according to general procedure and was purified by column chromatography with EtOAc/ $\mathrm{MeOH} / \mathrm{NH}_{3}$ (10:5:0.4) as eluent. Yield: $45 \%, \mathrm{mp} 255-258{ }^{\circ} \mathrm{C} .{ }^{1} \mathrm{H}$ NMR (DMSO- $\left.\mathrm{d}_{6}+\mathrm{D}_{2} \mathrm{O}\right) \delta 1.21\left(\mathrm{t}, 3 \mathrm{H}, \mathrm{CH}_{3}\right)$, 2.94-3.04 (m, 4H, CH 2$), 3.19$ (t, 2H, CH $), 3.27\left(\mathrm{t}, 2 \mathrm{H}, \mathrm{CH}_{2}\right), 3.59$ (t, $\left.2 \mathrm{H}, \mathrm{CH}_{2}\right), 4.67(\mathrm{t}, 2 \mathrm{H}$, Purin-N-CH $), 8.55(\mathrm{~s}, 2 \mathrm{H}, \mathrm{H}-8, \mathrm{H}-2) .{ }^{13} \mathrm{C}$ NMR $\left(\mathrm{DMSO}_{-} \mathrm{d}_{6}\right) \delta 12.00\left(\mathrm{CH}_{3}\right), 35.97,42.60,43.51 .44 .24\left(\mathrm{CH}_{2}-\mathrm{N}\right), 46.33$ ( $\mathrm{CH}_{2}$-purine N), 119.04 (C-5), 144.34 (C-8), 146.34 (C-6), 149.80 (C2), $151.51(\mathrm{C}-4)$. HRMS (ESI +$) \mathrm{m} / z$ calcd for $\mathrm{C}_{11} \mathrm{H}_{20} \mathrm{~N}_{7}(\mathrm{M}+\mathrm{H})^{+}$ 250.1780, found 250.1776. Anal. Calcd for $\mathrm{C}_{11} \mathrm{H}_{19} \mathrm{~N}_{7} .4 \mathrm{HCl} .0 .4 \mathrm{C}_{2} \mathrm{H}_{5} \mathrm{OH} .0 .2 \mathrm{H}_{2} \mathrm{O}$ : C, 33.97; $\mathrm{H}, 6.23 ; \mathrm{N}, 23.50$. Found $\mathrm{C}, 33.81 ; \mathrm{H}, 6.61 ; \mathrm{N}, 23.89$.

4.1.3.3. 9-[2-[2'-(N-Isopropylamino)ethyl]amino]ethyl-9H-adenine $\mathrm{HCl}$ (6). The compound was prepared from 3 and $\mathrm{N}$-isopropylethylenediamine according to general procedure and was purified by column chromatography with EtOAc/MeOH/NH (10:5:0.1) as eluent. Yield: $19.1 \%, \mathrm{mp} 216-218{ }^{\circ} \mathrm{C} .{ }^{1} \mathrm{H}$ NMR (DMSO$\left.\mathrm{d}_{6}+\mathrm{D}_{2} \mathrm{O}\right) \delta 1.19\left(\mathrm{~d}, 6 \mathrm{H}, \mathrm{CH}_{3}\right), 3.16-3.34\left(\mathrm{~m}, 5 \mathrm{H}, \mathrm{CH}, \mathrm{CH}_{2}\right), 3.52(\mathrm{t}, 2 \mathrm{H}$, $\left.\mathrm{CH}_{2}\right), 4.58(\mathrm{t}, 2 \mathrm{H}$, Purin-N-CH$), 8.44(\mathrm{~s}, 2 \mathrm{H}, \mathrm{H}-8, \mathrm{H}-2)$. HRMS (ESI+) $m / z$ calcd for $\mathrm{C}_{12} \mathrm{H}_{22} \mathrm{~N}_{7}(\mathrm{M}+\mathrm{H})^{+}$264.1937, found 264.1934. Anal. Calcd for $\mathrm{C}_{12} \mathrm{H}_{21} \mathrm{~N}_{7} .4 \mathrm{HCl} .0 .2 \mathrm{C}_{2} \mathrm{H}_{5} \mathrm{OH} .1 .0 \mathrm{H}_{2} \mathrm{O}$ : C, 34.12; H, 6.51; N, 22.46. Found C, 34.37; H, 6.59; N, 22.31. 

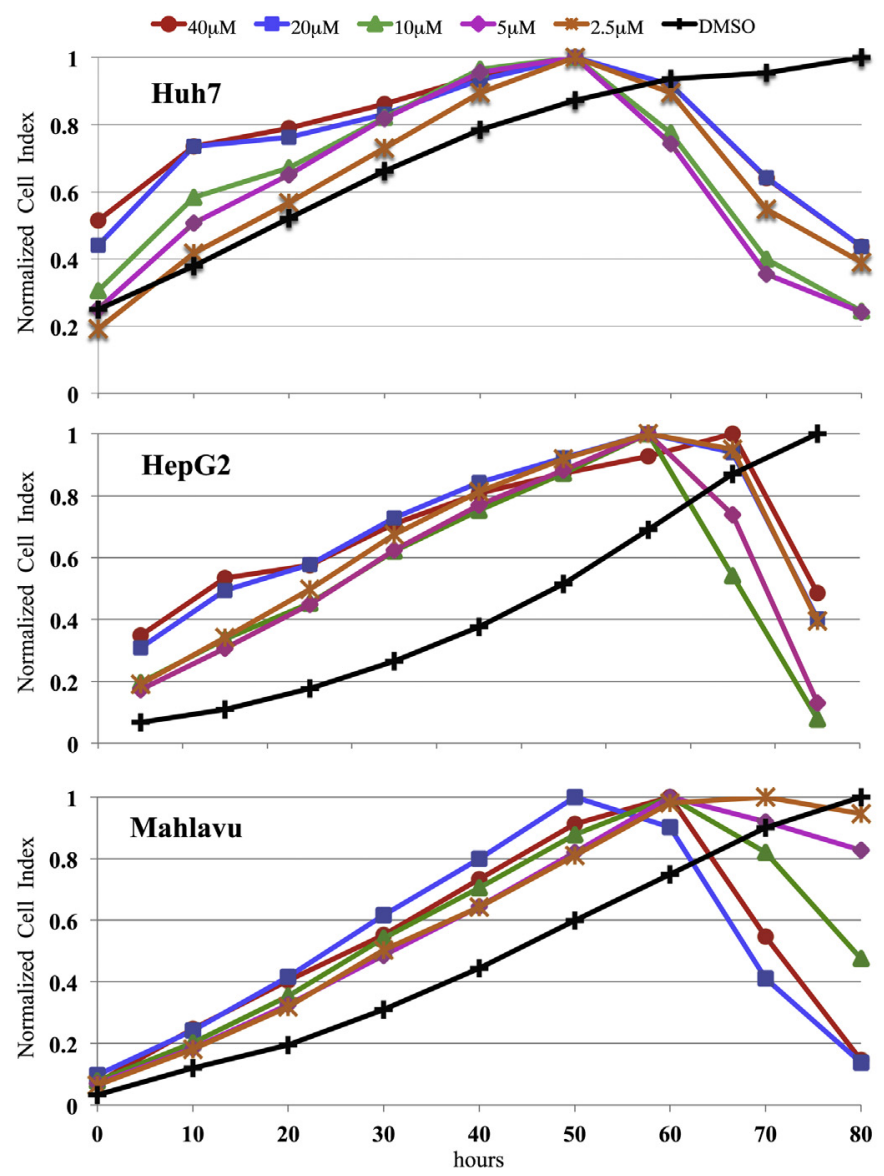

Fig. 8. Monitored real-time cell growth of Huh7, HepG2 and Mahlavu cells in the presence of compound 36. Purine analogue $\mathbf{3 6}$ and its DMSO control were administered to the liver cancer cells, inoculated in E-Plate 96, in triplicates. The cell growth index was monitored every $30 \mathrm{~min}$ in the presence of the five different concentrations of 36 (40 $\mu \mathrm{M}$-red, $20 \mu \mathrm{M}$-blue, $10 \mu \mathrm{M}$-green, $5 \mu \mathrm{M}$-pink, $2.5 \mu \mathrm{M}$-orange and DMSO control-black). (For interpretation of the references to colour in this figure legend, the reader is referred to the web version of this article.)
4.1.3.4. 9-[2-[2'-(N-Phenylamino)ethyl]amino]ethyl-9H-adenine (7). The compound was prepared from 3 and $\mathrm{N}$-phenylethylenediamine according to general procedure and was purified by column chromatography with EtOAc/MeOH/NH $3 \mathrm{NH}_{3}$ (10:5:0.1) as eluent. Yield: $20 \%$, mp 136-139 ${ }^{\circ} \mathrm{C} .{ }^{1} \mathrm{H}$ NMR(DMSO-d 6$) \delta 2.71\left(\mathrm{t}, 2 \mathrm{H}, \mathrm{CH}_{2}\right), 2.90-3.06$ $\left(\mathrm{m}, 4 \mathrm{H}, \mathrm{CH}_{2}\right), 4.18\left(\mathrm{t}, 2 \mathrm{H}\right.$, Purin- $\left.-\mathrm{CH}_{2}\right), 5.38(\mathrm{t}, 1 \mathrm{H}, \mathrm{Ph}-\mathrm{NH})$, 6.46-6.57 (m, 3H, H-2 $\left.2^{\prime}, 6^{\prime}, 4^{\prime}\right), 7.05\left(\mathrm{t}, 2 \mathrm{H}, \mathrm{H}-3^{\prime}, 5^{\prime}, J_{o}=7.6 \mathrm{~Hz}\right), 7.18$ (s, $\left.2 \mathrm{H}, \mathrm{NH}_{2}\right), 8.12(\mathrm{~s}, 1 \mathrm{H}$, purine $\mathrm{H}-8), 8.13(\mathrm{~s}, 1 \mathrm{H}, \mathrm{H}-2) .{ }^{13} \mathrm{C}$ NMR $($ DMSO-d 6$) \delta 43.50,43.77 .48 .39\left(\mathrm{CH}_{2}-\mathrm{N}\right), 48.85\left(\mathrm{CH}_{2}\right.$-purine $\left.\mathrm{N}\right)$, $112.66,116.23,119.36$ (CH in phenyl), $129.52(\mathrm{~N}-\mathrm{C}$ in phenyl), 141.89 (C-5), 149.57 (C-8), 150.29 (C-6), 152.94 (C-2), 156.60 (C-4). HRMS (ESI+) $m / z$ calcd for $\mathrm{C}_{15} \mathrm{H}_{20} \mathrm{~N}_{7}(\mathrm{M}+\mathrm{H})^{+} 298.1780$, found 298.1778 . Anal. Calcd for $\mathrm{C}_{15} \mathrm{H}_{19} \mathrm{~N}_{7}$ : C, 60.59; H, 6.44; N, 32.97. Found C, 60.77; $\mathrm{H}, 6.31 ; \mathrm{N}, 31.16$.

4.1.3.5. 9-[2-[2'-(1-Pyrrolidinyl)ethyl]amino]ethyl-9H-adenine $\mathrm{HCl}$ (8). The compound was prepared from 3 and 1-(2-aminoethyl) pyrrolidine according to general procedure and was purified by column chromatography with EtOAc/ $\mathrm{MeOH} / \mathrm{NH}_{3}$ (10:5:0.35) as eluent. Yield: $40.2 \%$, mp $185-187{ }^{\circ} \mathrm{C} .{ }^{1} \mathrm{H}$ NMR (DMSO- $\mathrm{d}_{6}+\mathrm{D}_{2} \mathrm{O}$ ) $\delta 1.99$ (br s, $4 \mathrm{H}$, pyrrole $\mathrm{CH}_{2}$ ), 3.08 (br s, $2 \mathrm{H}$, pyrrole $\mathrm{N}-\mathrm{CH}_{2}$ ), 3.40-3.68 (m, $8 \mathrm{H}, \mathrm{N}-\mathrm{CH}_{2}$, pyrrolidine $\left.\mathrm{N}-\mathrm{CH}_{2}\right), 4.67(\mathrm{t}, 2 \mathrm{H}$, purin$\mathrm{N}-\mathrm{CH}_{2}$ ), 8.54 (s, 2H, H-8, H-2). ${ }^{13} \mathrm{C}$ NMR (DMSO-d 6 ) $\delta 23.29$ (pyrrolidine $\left.\mathrm{N}-\mathrm{CH}_{2}\right), 42.98,46.36 .49 .68\left(\mathrm{CH}_{2}-\mathrm{N}\right), 63.77\left(\mathrm{CH}_{2}\right.$-purine N), 118.99 (C-5), 144.45 (C-8), 146.02 (C-6), 149.75 (C-2), 151.30 (C4). HRMS $(\mathrm{ESI}+) \mathrm{m} / z$ calcd for $\mathrm{C}_{13} \mathrm{H}_{22} \mathrm{~N}_{7}(\mathrm{M}+\mathrm{H})^{+} 276.1937$, found 276.1934. Anal. Calcd for $\mathrm{C}_{13} \mathrm{H}_{21} \mathrm{~N}_{7} .4 \mathrm{HCl} .0 .7 \mathrm{CH}_{3} \mathrm{OH} .1 .5 \mathrm{H}_{2} \mathrm{O}$ : C, 34.96; H, 6.59; N, 20.83. Found C, 34.66; H, 6.29; N, 20.49.

4.1.3.6. 9-[2-[2'-(4-Morpholinyl)ethyl]amino]ethyl-9H-adenine $\mathrm{HCl}$ (9). The compound was prepared from 3 and 4-(2-aminoethyl) morpholine according to general procedure and was purified by column chromatography with EtOAc/ $\mathrm{MeOH} / \mathrm{NH}_{3}$ (10:5:0.1) as eluent. Yield: $51.2 \%$, mp 218-220 ${ }^{\circ} \mathrm{C} .{ }^{1} \mathrm{H}$ NMR (DMSO- $\mathrm{d}_{6}+\mathrm{D}_{2} \mathrm{O}$ ) o 3.10-3.60 ( $\mathrm{m}, 14 \mathrm{H}, \mathrm{CH}_{2}$, morpholine $\left.\mathrm{CH}_{2}\right), 4.63(\mathrm{t}, 2 \mathrm{H}$, purin-N$\mathrm{CH}_{2}$ ), 8.49 (d, 2H, H-8, H-2). ${ }^{13} \mathrm{C}$ NMR (DMSO-d 6 ) $\delta 33.68$ (morpholine $\mathrm{N}-\mathrm{CH}_{2}$ ), 41.14 (morpholine $\left.\mathrm{O}-\mathrm{CH}_{2}\right), 46.37,52.08 .53 .79$ $\left(\mathrm{CH}_{2}-\mathrm{N}\right), 63.83\left(\mathrm{CH}_{2}\right.$-purine $\left.\mathrm{N}\right), 118.99(\mathrm{C}-5), 144.52(\mathrm{C}-8), 145.87$ (C-6), 149.76 (C-2), 151.21 (C-4). HRMS (ESI+) $\mathrm{m} / \mathrm{z}$ calcd for $\mathrm{C}_{13} \mathrm{H}_{22} \mathrm{~N}_{7} \mathrm{O}(\mathrm{M}+\mathrm{H})^{+}$292.1886, found 292.1876. Anal. Calcd for
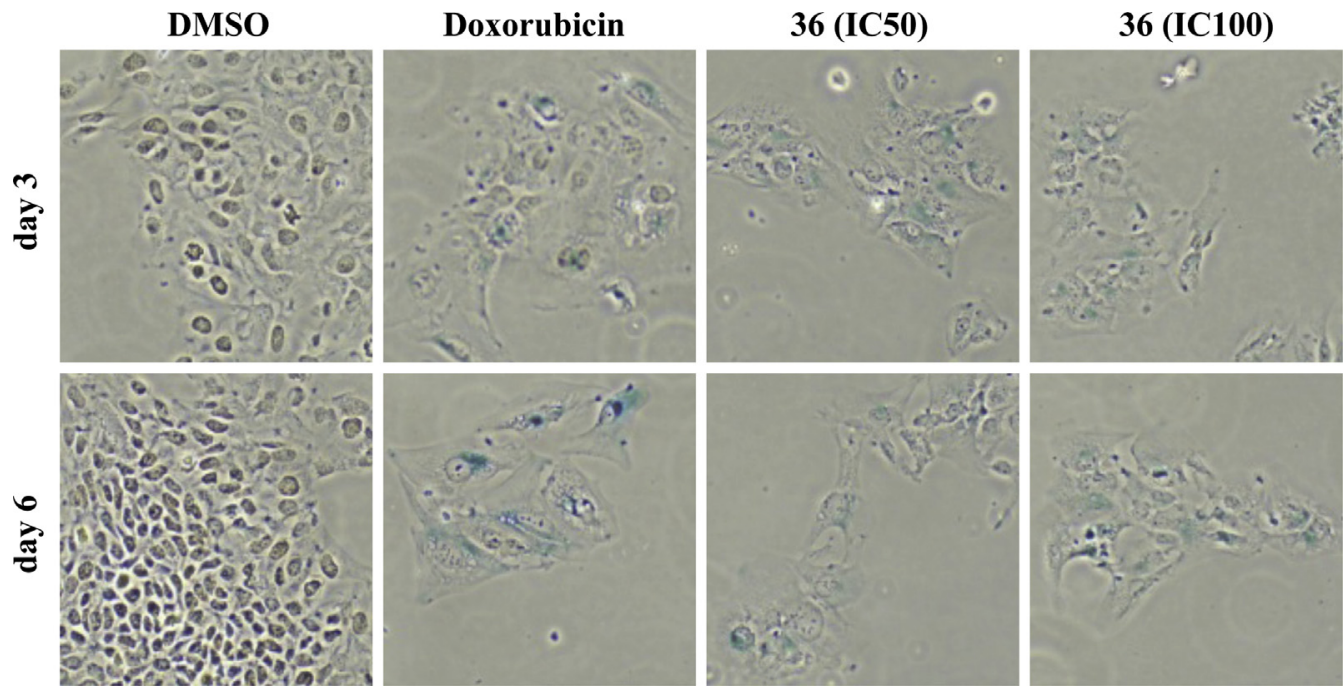

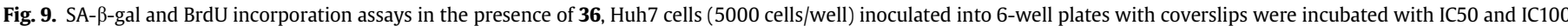

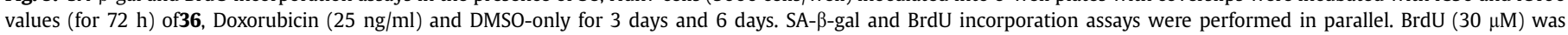
administered to the cells $24 \mathrm{~h}$ prior to the end of 3rd and 6th days of incubation. 
$\mathrm{C}_{13} \mathrm{H}_{21} \mathrm{~N}_{7} \mathrm{O} .4 \mathrm{HCl} .0 .5 \mathrm{CH}_{3} \mathrm{OH} .0 .5 \mathrm{H}_{2} \mathrm{O}$ : C, 35.08; $\mathrm{H}, 6.11 ; \mathrm{N}, 21.21$. Found C, 35.28; H, 5.81; N, 21.12.

4.1.3.7. 9-[2-(4-Methylpiperazin-1-yl)amino]ethyl-9H-adenine $\mathrm{HCl}$ (10). The compound was prepared from 3 and 1-amino-4methylpiperazine according to general procedure and was purified by column chromatography with EtOAc/MeOH/NH$/ \mathrm{NH}_{3}$ (10:5:0.1) as eluent. Yield: $10 \%, \mathrm{mp} 215-218{ }^{\circ} \mathrm{C} .{ }^{1} \mathrm{H}$ NMR (DMSO- $\mathrm{d}_{6}+\mathrm{D}_{2} \mathrm{O}$ ) $\delta 2.76\left(\mathrm{~s}, 3 \mathrm{H}, \mathrm{CH}_{3}\right), 2.88-3.60\left(\mathrm{~m}, 10 \mathrm{H}, \mathrm{CH}_{2}\right.$, piperazine $\left.\mathrm{CH}_{2}\right), 4.57(\mathrm{t}$, $2 \mathrm{H}$, purin-N-CH ), 8.47 (d, $2 \mathrm{H}, \mathrm{H}-8, \mathrm{H}-2)$. HRMS (ESI + ) $\mathrm{m} / \mathrm{z}$ calcd for $\mathrm{C}_{12} \mathrm{H}_{21} \mathrm{~N}_{8}(\mathrm{M}+\mathrm{H})^{+}$277.1889, found 277.1890. Anal. Calcd for $\mathrm{C}_{12} \mathrm{H}_{20} \mathrm{~N}_{8} .4 \mathrm{HCl} .0 .1 \mathrm{C}_{2} \mathrm{H}_{5} \mathrm{OH} .1 .0 \mathrm{H}_{2} \mathrm{O}$ : C, 32.94; H, 6.02; N, 25.19. Found C, 32.98; H, 5.96; N, 24.83 .

4.1.3.8. 9-[2-[4-(2-Hydroxyethyl)piperazine-1-yl]ethyl]-9H-adenine $\mathrm{HCl}$ (11). The compound was prepared from 3 and 1-(2hydroxyethyl)piperazine, according to general procedure and was purified by column chromatography with EtOAc/MeOH/NH (10:5:0.1) as eluent. Yield: $76.5 \%, \mathrm{mp} 243-246{ }^{\circ} \mathrm{C} .{ }^{1} \mathrm{H}$ NMR (DMSO$\left.\mathrm{d}_{6}+\mathrm{D}_{2} \mathrm{O}\right) \delta 3.18-3.53\left(\mathrm{~m}, 10 \mathrm{H}, \mathrm{CH}_{2}\right.$, piperazin $\left.\mathrm{CH}_{2}\right), 3.74\left(\mathrm{t}, 4 \mathrm{H}, \mathrm{CH}_{2}\right)$, $4.58\left(\mathrm{t}, 2 \mathrm{H}\right.$, purine- $\left.\mathrm{N}-\mathrm{CH}_{2}\right), 8.45(\mathrm{~s}, 1 \mathrm{H}, \mathrm{H}-8), 8.49(\mathrm{~s}, 1 \mathrm{H}, \mathrm{H}-2)$. HRMS (ESI+) $m / z$ calcd for $\mathrm{C}_{13} \mathrm{H}_{22} \mathrm{~N}_{7} \mathrm{O}(\mathrm{M}+\mathrm{H})^{+} 292.1886$, found 292.1883 . Anal. Calcd for $\mathrm{C}_{13} \mathrm{H}_{21} \mathrm{~N}_{7} \mathrm{O} .4 \mathrm{HCl} .1 .6 \mathrm{CH}_{3} \mathrm{OH}$ : C, 35.90; $\mathrm{H}, 6.48 ; \mathrm{N}$, 20.07. Found C, 35.95; H, 6.10; N, 19.71.

4.1.3.9. 9-[2-[4-[2-(Morpholine-4-yl)ethyl]piperazine-1-yl]ethyl]$9 \mathrm{H}$-adenine $\mathrm{HCl}(\mathbf{1 2})$. The compound was prepared from $\mathbf{3}$ and $1-$ [2-(morpholine-4-yl)ethyl]piperazine, according to general procedure and was purified by column chromatography with $\mathrm{CHCl}_{3}$ / $\mathrm{MeOH} / \mathrm{NH}_{3}$ (10:3:0.1) as eluent. Yield: $39.7 \%$, mp $265-268{ }^{\circ} \mathrm{C} .{ }^{1} \mathrm{H}$ NMR (DMSO- $\left.\mathrm{d}_{6}+\mathrm{D}_{2} \mathrm{O}\right) \delta 2.94-3.48\left(\mathrm{~m}, 22 \mathrm{H}, \mathrm{CH}_{2}\right.$, piperazin $\mathrm{CH}_{2}$, morpholine $\mathrm{CH}_{2}$ ), 4.60 (t, $2 \mathrm{H}$, purine- $\left.\mathrm{N}-\mathrm{CH}_{2}\right), 8.46$ (s, $\left.1 \mathrm{H}, \mathrm{H}-8\right), 8.57$ (s, 1H, H-2). HRMS (ESI+) $\mathrm{m} / z$ calcd for $\mathrm{C}_{17} \mathrm{H}_{29} \mathrm{~N}_{8} \mathrm{O}(\mathrm{M}+\mathrm{H})^{+}$ 361.2464, found 361.2460. Anal. Calcd for $\mathrm{C}_{17} \mathrm{H}_{28} \mathrm{~N}_{8} \mathrm{O}$.5 HCl.0.6$\mathrm{H}_{2} \mathrm{O} .0 .5 \mathrm{C}_{2} \mathrm{H}_{5} \mathrm{OH}$ : C, 37.40; H, 6.50; N, 19.43. Found C, 37.11; H, 6.34; $\mathrm{N}, 19.21$.

\subsubsection{6-Chloro-9-p-toluenesulfonyl-9H-purine (14)}

A solution of $\mathrm{KOH}(360 \mathrm{mg}, 6 \mathrm{mmol})$ in water $(15 \mathrm{ml})$ and then $p$ toluensulfonyl chloride ( $144 \mathrm{mg}, 6 \mathrm{mmol}$ ) were added dropwise to a stirred mixture of 6-chloropurine (13) $(464 \mathrm{mg}, 3 \mathrm{mmol})$ in acetone $(35 \mathrm{ml})$ at $0{ }^{\circ} \mathrm{C}$. The mixture was stirred at $0{ }^{\circ} \mathrm{C} 8 \mathrm{~h}$ and acetone was removed in vacuo. The solid was filtered off, washed with water and recrystallized from EtOH to yield $14(650 \mathrm{mg}$; 70.1\%): mp 172-175 ${ }^{\circ} \mathrm{C} .{ }^{1} \mathrm{H}$ NMR (DMSO-d 6 ) $\delta 2.39$ (s, 3H, $\left.\mathrm{CH}_{3}\right), 7.53$ $\left(\mathrm{d}, 2 \mathrm{H}, \mathrm{H}-3^{\prime}, 5^{\prime}, J_{o}=8.4 \mathrm{~Hz}\right), 8.14\left(\mathrm{~d}, 2 \mathrm{H}, \mathrm{H}-2^{\prime}, 6^{\prime}, J_{o}=8.4 \mathrm{~Hz}\right), 8.91(\mathrm{~s}$, $1 \mathrm{H}$, purine $\mathrm{H}-8), 9.16(\mathrm{~s}, 1 \mathrm{H}$, purine $\mathrm{H}-2)$. HRMS (ESI+) $\mathrm{m} / z$ calcd for $\mathrm{C}_{12} \mathrm{H}_{10} \mathrm{ClN}_{4} \mathrm{O}_{2} \mathrm{~S}(\mathrm{M}+\mathrm{H})^{+}$309.0213, found 309.0206. Anal. Cald for $\mathrm{C}_{12} \mathrm{H}_{9} \mathrm{ClN}_{4} \mathrm{O}_{2} \mathrm{~S} .0 .4 \mathrm{H}_{2} \mathrm{O}$ : C, 45.62; H, 3.13; N, 17.73; S, 10.15. Found $\mathrm{C}$, $45.91 ; \mathrm{H}, 3.52 ; \mathrm{N}, 18.11 ; \mathrm{S}, 10.51$.

\subsubsection{General procedure A for the synthesis of 6-substituted purines $(15,16,18,21,22,28)$}

6-Chloropurine (13) was dissolved in $5 \mathrm{ml}$ absolute EtOH, then the appropriate amine/piperazine/4-methylpiperidine and $(\mathrm{Et})_{3} \mathrm{~N}$ (1.7 equiv) were added. The mixture was refluxed for $8-40 \mathrm{~h}$. The reaction mixture was concentrated in vacuo and the residue was crystallized from EtOH.

\subsubsection{General procedure B for the synthesis of 6-substituted purines (17, 23-27, 29)}

A solution of 6-chloropurine (13) in $7 \mathrm{ml}$ of $\mathrm{n}-\mathrm{BuOH}$ was stirred at $70-80{ }^{\circ} \mathrm{C}$ for $0.5 \mathrm{~h}$ then the appropriate amine/piperazine and $(\mathrm{Et})_{3} \mathrm{~N}$ (1.7 equiv) were added. The mixture was heated at $90{ }^{\circ} \mathrm{C}$ for $4 \mathrm{~h}$. After cooling, the precipitated product was filtered off, washed with cold water and n-BuOH. The product was crystallized from EtOH.

\subsubsection{6-[4-(2-Hydroxyethyl)piperazine-1-yl]-9H-purine (15)}

The compound was prepared from 6-chloropurine (13) $(200 \mathrm{mg}$, $1.29 \mathrm{mmol})$ and $\mathrm{N}$-(2-hydroxyethyl)piperazine $(0.3 \mathrm{ml}, 2.45 \mathrm{mmol})$ according to general procedure A to yield $\mathbf{1 5}(228 \mathrm{mg}, 71 \%)$ : $\mathrm{mp}$ 230-234 ${ }^{\circ} \mathrm{C}$. ${ }^{1} \mathrm{H}$ NMR (DMSO-d $\left.{ }_{6}+\mathrm{D}_{2} \mathrm{O}\right) \delta 2.44(\mathrm{t}, J=6.4 \mathrm{~Hz}, 2 \mathrm{H}$, $\left.\mathrm{NCH}_{2}\right), 2.53$ (t, $4 \mathrm{H}$, piperazine $\left.\mathrm{CH}_{2}\right), 3.55\left(\mathrm{t}, J=6.4 \mathrm{~Hz}, 2 \mathrm{H}, \mathrm{OCH}_{2}\right)$, 4.21 (br s, $4 \mathrm{H}$, piperazine $\left.\mathrm{CH}_{2}\right), 8.11(\mathrm{~s}, 1 \mathrm{H}, \mathrm{H}-8), 8.20(\mathrm{~s}, 1 \mathrm{H}, \mathrm{H}-2)$. HRMS (ESI+) $m / z$ calcd for $\mathrm{C}_{11} \mathrm{H}_{17} \mathrm{~N}_{6} \mathrm{O}(\mathrm{M}+\mathrm{H})^{+} 249.1464$, found 249.1455. Anal. Calcd for $\mathrm{C}_{11} \mathrm{H}_{16} \mathrm{~N}_{6} \mathrm{O}$ : C, 53.21; $\mathrm{H}, 6.50 ; \mathrm{N}, 33.85$. Found C, 53.14; H, 6.13; N, 33.52.

\subsubsection{6-(1-Formylpiperazine-4-yl]-9H-purine (16)}

The compound was prepared from 6-chloropurine (13) $(200 \mathrm{mg}$, $1.29 \mathrm{mmol})$ and 1-piperazinecarboxaldehyde $(0.2 \mathrm{ml}, 1.94) \mathrm{ac}-$ cording to general procedure $\mathrm{A}$ and the product was purified by column chromatography $\left(\mathrm{CHCl}_{3} / \mathrm{MeOH} 10: 3\right)$ to yield 16 (179 mg, 60\%): mp 218-222 ${ }^{\circ} \mathrm{C} .{ }^{1} \mathrm{H}$ NMR (DMSO-d 6 ) $\delta 3.38-3.56(\mathrm{~m}, 6 \mathrm{H}$, piperazine $\mathrm{CH}_{2}$ ), 4.24 (br d, $2 \mathrm{H}$, piperazine $\left.\mathrm{CH}_{2}\right), 8.07$ (s, $1 \mathrm{H}, \mathrm{H}-8$ ), 8.12 (s, 1H, H-2), 8.17 (s, 1H, CHO), 8.25 (s, 1H, purine NH). HRMS (ESI+) $m / z$ calcd for $\mathrm{C}_{10} \mathrm{H}_{13} \mathrm{~N}_{6} \mathrm{O}(\mathrm{M}+\mathrm{H})^{+} 233.1151$, found 233.1147 . Anal. Calcd for $\mathrm{C}_{10} \mathrm{H}_{12} \mathrm{~N}_{6} \mathrm{O}: \mathrm{C}, 51.72 ; \mathrm{H}, 5.21 ; \mathrm{N}, 36.19$. Found $\mathrm{C}, 51.82$; H, 5.59; N, 36.48 .

\subsubsection{6-[4-(4-Trifluorophenyl)piperazin-1-yl]-9H-purine (17)}

The compound was prepared from 6-chloropurine (13) $(200 \mathrm{mg}$, $1.29 \mathrm{mmol}$ ) and $\mathrm{N}-(\alpha, \alpha, \alpha$-trifluoro-p-tolyl)piperazine (297 mg, $1.29 \mathrm{mmol}$ ) according to general procedure B to yield 17 (394 mg, 87.6\%): $\mathrm{mp} 286-289{ }^{\circ} \mathrm{C} .{ }^{1} \mathrm{H}$ NMR (DMSO-d $\left.\mathrm{d}_{6}\right) \delta 3.44(\mathrm{t}, 4 \mathrm{H}$, piperazine $\mathrm{CH}_{2}$ ), 4.37 (br s, $4 \mathrm{H}$, piperazine $\mathrm{CH}_{2}$ ), $7.13\left(\mathrm{~d}, J_{o}=8.8 \mathrm{~Hz}, 2 \mathrm{H}, \mathrm{H}-\right.$ $\left.2^{\prime}, 6^{\prime}\right), 7.54\left(\mathrm{~d}, J_{o}=8.8 \mathrm{~Hz}, 2 \mathrm{H}, \mathrm{H}-3^{\prime}, 5^{\prime}\right), 8.17(\mathrm{~s}, 1 \mathrm{H}$, purine $\mathrm{H}-8), 8.25$ (s, $1 \mathrm{H}$, purine $\mathrm{H}-2$ ), 13.08 (br s, $1 \mathrm{H}, \mathrm{NH}) .{ }^{13} \mathrm{C} \mathrm{NMR}$ (DMSO-d 6 ) $\delta 44.03$, $46.92\left(\mathrm{CH}_{2}\right.$ in piperazine), 114.29, 118.01 (q), 118.82123 .54 (C in phenyl), 126.11 (q) $\left(\mathrm{CF}_{3}\right), 138.29$ (C-5), 151.41 (C-8), 151.73 (C-6), 152.99 (C-2), 153.10 (C-4). HRMS (ESI+) $m / z$ calcd for $\mathrm{C}_{16} \mathrm{H}_{16} \mathrm{~F}_{3} \mathrm{~N}_{6}$ $(\mathrm{M}+\mathrm{H})^{+}$349.1389, found 349.1380. Anal. Calcd for $\mathrm{C}_{16} \mathrm{H}_{15} \mathrm{~F}_{3} \mathrm{~N}_{6}$ : C, 55.17; H, 4.34; N, 24.13; Found C, 55.00; H, 4.36; N, 24.19.

\subsubsection{6-(4-Methylpiperidin-1-yl)-9H-purine (18)}

The compound was prepared from 6-chloropurine (13) $(100 \mathrm{mg}$, $0.65 \mathrm{mmol})$ and 4-methylpiperidine $(0.1 \mathrm{ml}, 0.84 \mathrm{mmol})$ according to general procedure A to yield 18 [24] (72 mg, 51.4\%): mp264$266{ }^{\circ} \mathrm{C} .{ }^{1} \mathrm{H}$ NMR (DMSO-d 6$) \delta 0.92\left(\mathrm{~d}, 3 \mathrm{H}, \mathrm{CH}_{3}\right), 1.04-1.16(\mathrm{~m}, 1 \mathrm{H}$, piperidine $\mathrm{CH}$ ), 1.72 (br d, $4 \mathrm{H}$, piperidine $\mathrm{CH}_{2}$ ), $3.03(\mathrm{t}, 4 \mathrm{H}$, piperidine $\left.\mathrm{N}-\mathrm{CH}_{2}\right), 8.09$ (s, $\left.1 \mathrm{H}, \mathrm{H}-8\right), 8.18(\mathrm{~s}, 1 \mathrm{H}, \mathrm{H}-2), 13.00$ (br s, $1 \mathrm{H}, \mathrm{NH}$ ). HRMS (ESI+) $m / z$ calcd for $\mathrm{C}_{11} \mathrm{H}_{16} \mathrm{~N}_{5}(\mathrm{M}+\mathrm{H})^{+} 218.1406$, found 218.1411. Anal. Calcd for $\mathrm{C}_{11} \mathrm{H}_{15} \mathrm{~N}_{5}$ : C, 60.81; H, 6.96; N, 32.23.

\subsubsection{6-Cyclopropylamino-9H-purine (19)}

The compound was prepared from 6-chloropurine $(13)(200 \mathrm{mg}$, $1.29 \mathrm{mmol})$ and cyclopropylamine $(0.2 \mathrm{ml}, 2.85 \mathrm{mmol})$ according to general procedure A to yield 19 [45] (108 mg, 47.9\%): mp230$233^{\circ} \mathrm{C}$. ${ }^{1} \mathrm{H}$ NMR (DMSO-d $\left.{ }_{6}\right) \delta 0.61-0.65\left(\mathrm{~m}, 2 \mathrm{H}, \mathrm{CH}_{2}\right), 0.69-0.78(\mathrm{~m}$, $\left.2 \mathrm{H}, \mathrm{CH}_{2}\right), 3.03$ (br s, $\left.1 \mathrm{H}, \mathrm{NH}\right), 8.05$ (br s, $1 \mathrm{H}$, purine $\left.\mathrm{NH}\right), 8.15(\mathrm{~s}, 1 \mathrm{H}$, $\mathrm{H}-8), 8.26$ (s, $1 \mathrm{H}, \mathrm{H}-2)$. $\mathrm{HRMS}(\mathrm{ESI}+) \mathrm{m} / z$ calcd for $\mathrm{C}_{8} \mathrm{H}_{10} \mathrm{~N}_{5}(\mathrm{M}+\mathrm{H})^{+}$ 176.0936, found 176.0931. Anal. Cald for $\mathrm{C}_{8} \mathrm{H}_{9} \mathrm{~N}_{5} .0 .4 \mathrm{H}_{2} \mathrm{O}$ : C, 52.67; H, 5.41; N, 38.39. Found C, 52.29; H, 5.18; N, 38.45.

\subsubsection{6-(2-Hydroxyethyl)amino-9H-purine (20)}

The compound was prepared from 6-chloropurine (13) $(200 \mathrm{mg}$, $1.29 \mathrm{mmol})$ and 2-aminoethanol $(0.1 \mathrm{ml}, 1.64 \mathrm{mmol})$ according to general procedure A to yield 20 [46] (194 mg, 83.7\%): $\mathrm{mp}$ $247-250{ }^{\circ} \mathrm{C} .{ }^{1} \mathrm{H}$ NMR (DMSO-d 6 ) $\delta 3.57$ (br s, $4 \mathrm{H}, \mathrm{CH}_{2}$ ), 4.82 (br s, $1 \mathrm{H}$, 
$\mathrm{NH}), 7.46$ (br s, $1 \mathrm{H}$, purine $\mathrm{NH}$ ), 8.10 (s, $1 \mathrm{H}, \mathrm{H}-8), 8.18(\mathrm{~s}, 1 \mathrm{H}, \mathrm{H}-2)$. HRMS (ESI+) $m / z$ calcd for $\mathrm{C}_{7} \mathrm{H}_{10} \mathrm{~N}_{5} \mathrm{O}(\mathrm{M}+\mathrm{H})^{+} 180.0885$, found 180.0877

\subsubsection{6-(4-Methoxybenzyl)amino-9H-purine (21)}

The compound was prepared from 6-chloropurine (13) $(200 \mathrm{mg}$, $1.29 \mathrm{mmol}$ )and 4-(methoxybenzyl)amine $(0.25 \mathrm{ml}, 1.91 \mathrm{mmol})$ according to general procedure B to yield 21 [47] (260 mg, 78.8\%): mp 246-250 ${ }^{\circ} \mathrm{C} .{ }^{1} \mathrm{H}$ NMR (DMSO-d $\left.6+\mathrm{D}_{2} \mathrm{O}\right) \delta 3.71\left(\mathrm{~s}, 3 \mathrm{H}, \mathrm{OCH}_{3}\right), 4.64(\mathrm{br}$ $\mathrm{s}, 2 \mathrm{H}, \mathrm{CH}_{2}$ ), $6.87\left(\mathrm{~d}, J_{o}=8.4 \mathrm{~Hz}, 2 \mathrm{H}, \mathrm{H}-3^{\prime}, 5^{\prime}\right), 7.30$ (d, $J_{o}=8.4 \mathrm{~Hz}, 2 \mathrm{H}$, $\left.\mathrm{H}-2^{\prime}, 6^{\prime}\right), 8.11$ (s, $1 \mathrm{H}$, purine $\left.\mathrm{H}-8\right), 8.19$ (s, $1 \mathrm{H}$, purine $\left.\mathrm{H}-2\right)$. HRMS $(\mathrm{ESI}+) \mathrm{m} / z$ calcd for $\mathrm{C}_{13} \mathrm{H}_{14} \mathrm{~N}_{5} \mathrm{O}(\mathrm{M}+\mathrm{H})^{+} 256.1198$, found 256.1188 . Anal. Cald for $\mathrm{C}_{13} \mathrm{H}_{13} \mathrm{~N}_{5} \mathrm{O} .0 .2 \mathrm{H}_{2} \mathrm{O}: \mathrm{C}, 60.31 ; \mathrm{H}, 5.21 ; \mathrm{N}, 27.05$. Found C, $60.21 ; \mathrm{H}, 5.02 ; \mathrm{N}, 26.78$.

\subsubsection{6-[3-(Trifluoromethyl)benzyl]amino-9H-purine (22)}

The compound was prepared from 6-chloropurine $(13)(200 \mathrm{mg}$, $1.29 \mathrm{mmol}$ ) and 3-(trifluoromethyl)benzylamine $(0.25 \mathrm{ml}$, $1.75 \mathrm{mmol}$ ) according to general procedure B to yield $\mathbf{2 2}(200 \mathrm{mg}$, 52.7\%): $\mathrm{mp} 250-253{ }^{\circ} \mathrm{C} .{ }^{1} \mathrm{H}$ NMR (DMSO-d 6 ) $\delta 4.78$ (br s, $2 \mathrm{H}, \mathrm{CH}_{2}$ ), 7.52-7.71 ( $\mathrm{m}, 4 \mathrm{H}, \mathrm{H}-\mathrm{Ph}), 8.15$ (d, 2H, purine $\mathrm{H}-8, \mathrm{H}-2), 8.35$ (br s, $1 \mathrm{H}$, $\mathrm{NH}), 12.96$ (br s, $1 \mathrm{H}$, purine NH). ${ }^{13} \mathrm{C}$ NMR (DMSO-d 6$) \delta 43.20\left(\mathrm{CH}_{2}\right)$, 123.61, 124.0 (q), 124.34 (q), 126.33, 129.41, 129.72 (C in phenyl), $129.94\left(\mathrm{CF}_{3}\right), 132.03$ (C-5), 139.75 (C-8), 142.51 (C-6), $153.0(\mathrm{C}-2)$, 154.79 (C-4). HRMS (ESI+) $\mathrm{m} / z$ calcd for $\mathrm{C}_{13} \mathrm{H}_{11} \mathrm{~F}_{3} \mathrm{~N}_{5}(\mathrm{M}+\mathrm{H})^{+}$ 294.0967, found 294.0963. Anal. Cald for $\mathrm{C}_{13} \mathrm{H}_{10} \mathrm{~F}_{3} \mathrm{~N}_{5}$ : C, 53.24; $\mathrm{H}$, 3.44; N, 23.88. Found C, 53.13; H, 3.47; N, 23.76.

\subsubsection{6-(2,4-Difluorobenzyl)amino-9H-purine (23)}

The compound was prepared from 6-chloropurine (13) $(200 \mathrm{mg}$, $1.29 \mathrm{mmol})$ and 2,4-difluorobenzylamine $(0.2 \mathrm{ml}, 1.68 \mathrm{mmol})$ according to general procedure B to yield 23 [47] (255 mg, 75.8\%): $\mathrm{mp}$ 263-265 ${ }^{\circ} \mathrm{C}$. ${ }^{1} \mathrm{H}$ NMR (DMSO-d 6 ) $\delta 4.68$ (br s, $\left.2 \mathrm{H}, \mathrm{CH}_{2}\right), 6.98(\mathrm{t}$, $\left.J_{o}=8.4 \mathrm{~Hz}, 1 \mathrm{H}, \mathrm{H}-3^{\prime}\right), 7.18\left(\mathrm{t}, J_{o}=8.4 \mathrm{~Hz}, 1 \mathrm{H}, \mathrm{H}-5^{\prime}\right), 7.35\left(\mathrm{~d}, J_{o}=7.2 \mathrm{~Hz}\right.$ $\left.1 \mathrm{H}, \mathrm{H}-6^{\prime}\right), 8.12(\mathrm{~d}, 3 \mathrm{H}$, purine $\mathrm{H}-8, \mathrm{H}-2, \mathrm{NH}), 12.91$ (br s, $1 \mathrm{H}$, purine $\mathrm{NH}) .{ }^{13} \mathrm{C}$ NMR (DMSO-d 6$) \delta 37.13\left(\mathrm{CH}_{2}\right), 104.20(\mathrm{t}), 111.83(\mathrm{C}$ in phenyl), 123.70 (C-5), 130.94 (C-8), 139.78 (C-6), 152.97 (C-2), 154.85 (C-4), 159.44, 160.66, 161.77, 163.03 (C in phenyl). HRMS (ESI+) $\mathrm{m} / \mathrm{z}$ calcd for $\mathrm{C}_{12} \mathrm{H}_{10} \mathrm{~F}_{2} \mathrm{~N}_{5}(\mathrm{M}+\mathrm{H})^{+} 262.0904$, found 262.0903. Anal. Cald for $\mathrm{C}_{12} \mathrm{H}_{9} \mathrm{~F}_{2} \mathrm{~N}_{5}$ : C, 55.17; H, 3.47; N, 26.81 . Found C, 55.49; H, 3.53, N, 26.67.

\subsubsection{6-(2,4-Dichlorobenzyl)amino-9H-purine (24)}

The compound was prepared from 6-chloropurine (13) $(200 \mathrm{mg}$, $1.29 \mathrm{mmol})$ and 2,4-dichlorobenzylamine $(0.23 \mathrm{ml}, 1.73 \mathrm{mmol})$ according to general procedure B to yield 24 [47] (353 mg, 92.9\%):mp 286-290 ${ }^{\circ} \mathrm{C} .{ }^{1} \mathrm{H}$ NMR (DMSO-d 6 ) $\delta 4.71$ (br s, $2 \mathrm{H}, \mathrm{CH}_{2}$ ), $7.28\left(\mathrm{~d}, J_{o}=8.4 \mathrm{~Hz} 1 \mathrm{H}, \mathrm{H}-6^{\prime}\right), 7.36\left(\mathrm{dd}, J_{o}=8 \mathrm{~Hz}, J_{m}=2 \mathrm{~Hz}, 1 \mathrm{H}, \mathrm{H}-5^{\prime}\right)$, $7.61\left(\mathrm{~d}, J_{m}=1.6 \mathrm{~Hz}, 1 \mathrm{H}, \mathrm{H}-3^{\prime}\right), 8.15(\mathrm{~s}, 2 \mathrm{H}$, purine $\mathrm{H}-8, \mathrm{H}-2), 8.28(\mathrm{br}$ $\mathrm{s}, 1 \mathrm{H}, \mathrm{NH}), 12.98$ (br s, $1 \mathrm{H}$, purine NH). HRMS (ESI+) $\mathrm{m} / z$ calcd for $\mathrm{C}_{12} \mathrm{H}_{10} \mathrm{Cl}_{2} \mathrm{~N}_{5}(\mathrm{M}+\mathrm{H})^{+}$294.0313, found 294.0317. Anal. Cald for $\mathrm{C}_{12} \mathrm{H}_{9} \mathrm{Cl}_{2} \mathrm{~N}_{5} \cdot 0.2 \mathrm{CH}_{3} \mathrm{OH}$ : C, 48.75; H, 3.29; N, 23.30. Found C, 48.60; $\mathrm{H}, 2.99$; N, 22.95 .

\subsubsection{6-[2-(N-Phenylamino)ethyl]amino-9H-purine (25)}

The compound was prepared from 6-chloropurine (13) $(200 \mathrm{mg}$, $1.29 \mathrm{mmol})$ and $\mathrm{N}$-phenylethlenediamine $(0.2 \mathrm{ml}, 1.53 \mathrm{mmol})$ according to general procedure B to yield 25 [24] (290 mg, 88.1\%): mp 253-255 ${ }^{\circ} \mathrm{C} .{ }^{1} \mathrm{H}$ NMR (DMSO-d 6 ) $\delta 3.31$ (q, 2H, $\mathrm{CH}_{2}$ ),3.72 (br s, $2 \mathrm{H}$, $\left.\mathrm{CH}_{2}\right), 5.84(\mathrm{t}, 1 \mathrm{H}, \mathrm{NH}), 6.57\left(\mathrm{t}, J_{0}=7.2 \mathrm{~Hz}, 1 \mathrm{H}, \mathrm{H}-4^{\prime}\right), 6.68(\mathrm{~d}$, $\left.J_{o}=8.4 \mathrm{~Hz}, 2 \mathrm{H}, \mathrm{H}-2^{\prime}, 6^{\prime}\right), 7.13\left(\mathrm{t}, J_{o}=7.6 \mathrm{~Hz}, 2 \mathrm{H}, \mathrm{H}-3^{\prime}, 5^{\prime}\right), 7.79(\mathrm{br} \mathrm{s}, 1 \mathrm{H}$, $\mathrm{NH}), 8.16(\mathrm{~s}, 1 \mathrm{H}$, purine $\mathrm{H}-8), 8.28(\mathrm{~s}, 1 \mathrm{H}$, purine $\mathrm{H}-2), 13.00(\mathrm{br} \mathrm{s}, 1 \mathrm{H}$, purine $\mathrm{NH})$. HRMS $(\mathrm{ESI}+) \mathrm{m} / \mathrm{z}$ calcd for $\mathrm{C}_{13} \mathrm{H}_{15} \mathrm{~N}_{6}(\mathrm{M}+\mathrm{H})^{+}$ 255.1358, found 255.1350. Anal. Calcd for $\mathrm{C}_{13} \mathrm{H}_{14} \mathrm{~N}_{6}$ : C, 61.40; $\mathrm{H}$, 5.55; N, 33.05. Found C, 61.04; H, 5.46; N, 32.95.

\subsubsection{6-(2-Cyclohexenylethyl)amino-9H-purine (26)}

The compound was prepared from 6-chloropurine (13) $150 \mathrm{mg}$, $0.97 \mathrm{mmol})$ and 2-(1-cyclohexenyl)ethylamine $(0.27 \mathrm{ml}$, $1.94 \mathrm{mmol}$ ) according to general procedure $A$ and the product was purified by column chromatography (EtOAc/MeOH 10:1) to yield 26 [24] (160 mg, 68\%): mp 197-200 ${ }^{\circ} \mathrm{C} .{ }^{1} \mathrm{H}$ NMR (DMSO-d ${ }_{6}$ ) $\delta 1.51$ (dd, $\left.4 \mathrm{H}, \mathrm{CH}_{2}\right), 1.94\left(\mathrm{~d}, 4 \mathrm{H}, \mathrm{CH}_{2}\right), 2.22\left(\mathrm{t}, 2 \mathrm{H}, \mathrm{CH}_{2}\right), 3.55$ (br s, $2 \mathrm{H}$, $\left.\mathrm{NH}-\mathrm{CH}_{2}\right), 5.41(\mathrm{~s}, 1 \mathrm{H},=\mathrm{CH}), 7.52($ br s, $1 \mathrm{H}, \mathrm{NH}), 8.07(\mathrm{~s}, 1 \mathrm{H}$, purine $\mathrm{H}-8), 8.17$ (s, 1H, purine $\mathrm{H}-2$ ), 12.88 (br s, 1H, purine NH). HRMS (ESI+) $m / z$ calcd for $\mathrm{C}_{13} \mathrm{H}_{18} \mathrm{~N}_{5}(\mathrm{M}+\mathrm{H})^{+} 244.1562$, found 244.1553 . Anal.Calcd for $\mathrm{C}_{13} \mathrm{H}_{17} \mathrm{~N}_{5}$ : C, 64.17; $\mathrm{H}, 7.04 ; \mathrm{N}, 28.78$. Found C, 63.85; H, 6.65; N, 28.39.

\subsubsection{6-(1-Benzylpiperidine-4-yl)amino-9H-purine (27)}

The compound was prepared from 6-chloropurine (13) $(200 \mathrm{mg}$, $1.29 \mathrm{mmol})$ and 4-amino-1-benzylpiperidine $(0.35 \mathrm{ml}, 1.71 \mathrm{mmol})$ according to general procedure B to yield 27 (170 mg, 42.6\%): $\mathrm{mp}$ 279-282 ${ }^{\circ} \mathrm{C} .{ }^{1} \mathrm{H}$ NMR (DMSO- $\left.\mathrm{d}_{6}\right) \delta 1.87-2.20(\mathrm{~m}, 4 \mathrm{H}$, piperidine 3,5- $\left.\mathrm{CH}_{2}\right), 3.00-3.26\left(\mathrm{~m}, 4 \mathrm{H}\right.$, piperidine $\left.2,6-\mathrm{CH}_{2}\right), 4.28(\mathrm{br} \mathrm{s}, 3 \mathrm{H}$, piperidine 4-CH, benzyl $\mathrm{CH}_{2}$ ), $7.46\left(\mathrm{~s}, 3 \mathrm{H}, \mathrm{H}-2^{\prime}, 4^{\prime}, 6^{\prime}\right), 7.59(\mathrm{~s}, 2 \mathrm{H}, \mathrm{H}-$ $\left.3^{\prime}, 5^{\prime}\right), 7.87$ (br s, $\left.1 \mathrm{H}, \mathrm{NH}\right), 8.17$ (d, 2H, purine $\left.\mathrm{H}-8, \mathrm{H}-2\right), 12.99$ (br s, $1 \mathrm{H}$, purine $\mathrm{NH})$. HRMS $(\mathrm{ESI}+) \mathrm{m} / z$ calcd for $\mathrm{C}_{17} \mathrm{H}_{21} \mathrm{~N}_{6}(\mathrm{M}+\mathrm{H})^{+}$ 309.1828, found 309.1819. Anal. Calcd for $\mathrm{C}_{17} \mathrm{H}_{20} \mathrm{~N}_{6}$ : C, 66.21; $\mathrm{H}$, 6.54; N, 27.25. Found C, 66.48; H, 6.17; N, 27.54.

\subsubsection{General procedure for the sulfonylation of 6-substituted purines (preparation of compounds 28-34)}

A solution of $p$-toluenesulfonylchloride (2 equiv) in $5 \mathrm{ml} \mathrm{CH} \mathrm{Cl}_{2}$ was slowly added to a solution of 6 -substituted purines (28-34) in $1 \mathrm{ml}$ pyridine. The reaction mixture was stirred for $24 \mathrm{~h}$ in an ice bath. The reaction mixture was treated with $1 \mathrm{~N} \mathrm{HCl}(5 \mathrm{ml})$ and extracted with $\mathrm{CH}_{2} \mathrm{Cl}_{2}$. The extract was dried over $\mathrm{Na}_{2} \mathrm{SO}_{4}$, the solvent was evaporated in vacuo, and the residue was purified by column chromatography.

4.1.20.1. 6-[4-(4-Trifluoromethylphenyl)piperazin-1-yl]-9-p-toluenesulfonyl-9H-purine (28). The compound was prepared from 6-[4(4-Trifluorophenyl)piperazin-1-yl]-9H-purine (17) (230 mg, $0.66 \mathrm{mmol}$ ) according to general procedure and was purified by column chromatography (EtOAc-hexane, 1:1) to yield $\mathbf{2 8}(170 \mathrm{mg}$; 50.6\%): mp 219-221 ${ }^{\circ} \mathrm{C} .{ }^{1} \mathrm{H}$ NMR (DMSO-d 6 ) $\delta 2.39\left(\mathrm{~s}, 3 \mathrm{H}, \mathrm{CH}_{3}\right), 3.43$ $\left(\mathrm{t}, 4 \mathrm{H}\right.$, piperazine $\left.\mathrm{CH}_{2}\right), 4.31$ (br s, $4 \mathrm{H}$, piperazine $\left.\mathrm{CH}_{2}\right), 7.10(\mathrm{~d}$, $\left.J_{o}=8.4 \mathrm{~Hz}, 2 \mathrm{H}, \mathrm{H}-2^{\prime}, 6^{\prime}\right), 7.51\left(\mathrm{~m}, 4 \mathrm{H}, \mathrm{H}-3^{\prime}, 5^{\prime}, p\right.$-toluene $\left.\mathrm{H}-3,5\right), 8.10$ $\left(\mathrm{d}, J_{0}=8.4 \mathrm{~Hz}, 2 \mathrm{H}, p\right.$-toluene $\left.\mathrm{H}-2,6\right), 8.35(\mathrm{~s}, 1 \mathrm{H}$, purine $\mathrm{H}-2), 8.71$ (s, $1 \mathrm{H}$, purine $\mathrm{H}-8) .{ }^{13} \mathrm{C}$ NMR (DMSO-d 6$) \delta 21.85\left(\mathrm{CH}_{3}\right), 45.08,47.42$ ( $\mathrm{CH}_{2}$ in piperazine), $114.98,118.80(\mathrm{q}), 119.83,124.24$ ( $\mathrm{C}$ in phenyl), $126.88(\mathrm{q})\left(\mathrm{CF}_{3}\right), 128.87,130.97,134.02$ (C in phenyl), $137.92(\mathrm{C}-5)$, 147.46 (C in phenyl), 150.09 (C-8), 153.63 (C-6), 153.78 (C-2), 154.25 (C-4). HRMS (ESI + ) $m / z$ calcd for $\mathrm{C}_{23} \mathrm{H}_{22} \mathrm{~F}_{3} \mathrm{~N}_{6} \mathrm{O}_{2} \mathrm{~S}(\mathrm{M}+\mathrm{H})^{+} 503.1477$, 503.1472. Anal. Calcd for $\mathrm{C}_{23} \mathrm{H}_{21} \mathrm{~F}_{3} \mathrm{~N}_{6} \mathrm{O}_{2} \mathrm{~S}$ : C, 54.97; $\mathrm{H}, 4.21 ; \mathrm{N}, 16.72$; S, 6.38; Found C, 54.75; H, 4.13; N, 16.53; S, 6.25.

4.1.20.2. 6-(4-Methylpiperidin-1-yl)-9-p-toluenesulfonyl-9H-purine (29). The compound was prepared from 6-(4-methylpiperidin-1yl)-9H-purine (18) (100 mg, $0.46 \mathrm{mmol}$ ) according to general procedure and was purified by column chromatography (EtOAc-hexane, $1: 2)$ to yield 29 (110 g, 62\%): $\mathrm{mp} 156-157{ }^{\circ} \mathrm{C} .{ }^{1} \mathrm{H}$ NMR(DMSO$\left.\mathrm{d}_{6}\right) \delta 0.89\left(\mathrm{~d}, 3 \mathrm{H}\right.$, piperidine $\left.\mathrm{CH}_{3}\right), 1.00-1.14(\mathrm{~m}, 1 \mathrm{H}$, piperidine $\mathrm{CH})$, $1.71\left(\mathrm{~d}, 4 \mathrm{H}\right.$, piperidine $\left.\mathrm{CH}_{2}\right), 2.39\left(\mathrm{~s}, 3 \mathrm{H}, \mathrm{CH}_{3}\right), 2.96-3.12$ (br s, $4 \mathrm{H}$, piperidine $\left.\mathrm{N}-\mathrm{CH}_{2}\right), 7.50\left(\mathrm{~d}, J_{o}=8 \mathrm{~Hz}, 2 \mathrm{H}, p\right.$-toluene $\left.\mathrm{H}-3,5\right), 8.09$ (d, $J_{o}=8.4 \mathrm{~Hz}, 2 \mathrm{H}, p$-toluene $\left.\mathrm{H}-2,6\right), 8.28(\mathrm{~s}, 1 \mathrm{H}$, purine $\mathrm{H}-2), 8.64(\mathrm{~s}$, $1 \mathrm{H}$, purine $\mathrm{H}-8) .{ }^{13} \mathrm{C}$ NMR (DMSO- $\left.\mathrm{d}_{6}\right) \delta 21.85,22.26\left(\mathrm{CH}_{3}\right), 31.07$, $34.38,45.54\left(\mathrm{CH}_{2}\right.$ in piperidine $), 119.62,128.90,130.96,134.08$ (C in phenyl), 137.36 (C-5), 147.40 (C-8), 150.05 (C-6), 153.67 (C-2), 154.27 (C-4). HRMS (ESI+) $\mathrm{m} / z$ calcd for $\mathrm{C}_{18} \mathrm{H}_{22} \mathrm{~N}_{5} \mathrm{O}_{2} \mathrm{~S}(\mathrm{M}+\mathrm{H})^{+} 372.1494$, 
found 372.1493. Anal. Calcd for $\mathrm{C}_{18} \mathrm{H}_{21} \mathrm{~N}_{5} \mathrm{O}_{2} \mathrm{~S}$ : C, 58.20; $\mathrm{H}, 5.70 ; \mathrm{N}$, $18.85 ;$ S, 8.63. Found C, 58.51; H, 5.84; N, 19.00; S, 8.70.

4.1.20.3. 6-Cyclopropylamino-9-p-toluenesulfonyl-9H-purine (30). The compound was prepared from 6-cyclopropylamino-9H-purine (19) $(90 \mathrm{mg}, 0.51 \mathrm{mmol}$ ) according to general procedure and was purified by column chromatography (EtOAc-hexane, 1:1) to yield 30 (47 mg, 27.8\%): $\mathrm{mp} 173-176{ }^{\circ} \mathrm{C} .{ }^{1} \mathrm{H}$ NMR (DMSO-d ${ }_{6}$ ) $\delta 0.58-0.76$ $\left(\mathrm{m}, 4 \mathrm{H}, \mathrm{CH}_{2}\right), 2.38\left(\mathrm{~s}, 3 \mathrm{H}, \mathrm{CH}_{3}\right), 7.50\left(\mathrm{~d}, J_{o}=9.2 \mathrm{~Hz}, 2 \mathrm{H}, p\right.$-toluene $\mathrm{H}-$ 3,5), $8.09\left(\mathrm{~d}, J_{o}=8.8 \mathrm{~Hz}, 2 \mathrm{H}, \mathrm{p}\right.$-toluene $\left.\mathrm{H}-2,6\right), 8.34$ (br s, $2 \mathrm{H}$, purine $\mathrm{H}-2, \mathrm{NH}), 8.63(\mathrm{~s}, 1 \mathrm{H}$, purine $\mathrm{H}-8) .{ }^{13} \mathrm{C}$ NMR (DMSO-d 6$) \delta 7.45\left(\mathrm{CH}_{2}\right.$ in cyclopropyl), $21.87\left(\mathrm{CH}_{3}\right), 24.25$ ( $\mathrm{CH}$ in cyclopropyl), 119.85, 128.76, 131.0, 134.24 (C in phenyl), 138.70 (C-5), 147.36 (C-8), 148.47 (C-6), 154.97 (C-2), 156.37 (C-4). HRMS (ESI+) $\mathrm{m} / \mathrm{z}$ calcd for $\mathrm{C}_{15} \mathrm{H}_{16} \mathrm{~N}_{5} \mathrm{O}_{2} \mathrm{~S}(\mathrm{M}+\mathrm{H})^{+} 330.1025$, found 330.1033. Anal. Calcd for $\mathrm{C}_{15} \mathrm{H}_{15} \mathrm{~N}_{5} \mathrm{O}_{2} \mathrm{~S} .0 .1 \mathrm{C}_{6} \mathrm{H}_{14}$ : C, 55.43; H, 4.89; N, 20.72; S, 9.48; Found $\mathrm{C}$, 55.43; H, 4.99; N, 21.04; S, 9.49.

4.1.20.4. 6-(4-Methoxybenzyl)amino-9-p-toluenesulfonyl-9H-purine (31). The compound was prepared from 6-(4-methoxybenzyl) amino-9H-purine (21) (100 $\mathrm{mg}, 0.39 \mathrm{mmol}$ ) according to general procedure and was purified by column chromatography (EtOAchexane, $1: 1$ ) to yield 31 (27 mg, 16.9\%): mp 163-165 ${ }^{\circ} \mathrm{C} .{ }^{1} \mathrm{H}$ NMR $\left(\mathrm{DMSO}_{-} \mathrm{d}_{6}\right) \delta 2.35\left(\mathrm{~s}, 3 \mathrm{H}, \mathrm{CH}_{3}\right), 3.66\left(\mathrm{~s}, 3 \mathrm{H}, \mathrm{OCH}_{3}\right), 4.56\left(\mathrm{~d}, 2 \mathrm{H}, \mathrm{CH}_{2}\right)$, $6.80\left(\mathrm{~d}, J_{o}=8.4 \mathrm{~Hz}, 2 \mathrm{H}, \mathrm{H}-3^{\prime}, 5^{\prime}\right), 7.21\left(\mathrm{~d}, J_{o}=8.4 \mathrm{~Hz}, 2 \mathrm{H}, \mathrm{H}-2^{\prime}, 6^{\prime}\right), 7.46$ (d, $J_{o}=8.4 \mathrm{~Hz}, 2 \mathrm{H}, p$-toluene H-3,5), 8.06 (d, $J_{o}=8.4 \mathrm{~Hz}, 2 \mathrm{H}, p$ toluene $\mathrm{H}-2,6), 8.26(\mathrm{~s}, 1 \mathrm{H}$, purine $\mathrm{H}-2), 8.60(\mathrm{~s}, 1 \mathrm{H}$, purine $\mathrm{H}-8)$, 8.66 (br s, $1 \mathrm{H}, \mathrm{NH}) .{ }^{13} \mathrm{C}$ NMR $\left(\mathrm{DMSO}_{-} \mathrm{d}_{6}\right) \delta 21.85\left(\mathrm{CH}_{3}\right), 43.08\left(\mathrm{CH}_{2}\right)$, $55.66\left(\mathrm{OCH}_{3}\right), 114.29,119.89,128.76,129.22,130.99,132.05,134.20$ (C in phenyl), 138.85 (C-5), 147.37 (C-8), 148.36 (C-6), 155.01 (C-2), 155.08 (C-4), 158.83 (C in phenyl). HRMS (ESI+) $\mathrm{m} / z$ calcd for $\mathrm{C}_{20} \mathrm{H}_{20} \mathrm{~N}_{5} \mathrm{O}_{3} \mathrm{~S}(\mathrm{M}+\mathrm{H})^{+}$410.1287, found 410.1279. Anal. Calcd for $\mathrm{C}_{20} \mathrm{H}_{19} \mathrm{~N}_{5} \mathrm{O}_{3} \mathrm{~S}$ : C, 58.67; H, 4.68; N, 17.10; S, 7.83; Found C, 58.82; H, $4.95 ; \mathrm{N}, 16.88 ; \mathrm{S}, 7.72$.

4.1.20.5. 6-(2,4-Difluorobenzyl)amino-9-p-toluenesulfonyl-9H-purine (32). The compound was prepared from 6-(2,4difluorobenzyl)amino-9H-purine (23) (150 $\mathrm{mg}, 0.57 \mathrm{mmol}$ ) according to general procedure and was purified by column chromatography (EtOAc-hexane, 1:2) to yield 32 (70 mg, 29.3\%): mp 153-156 ${ }^{\circ} \mathrm{C} .{ }^{1} \mathrm{H}$ NMR (DMSO-d 6 ) $\delta 2.38\left(\mathrm{~s}, 3 \mathrm{H}, \mathrm{CH}_{3}\right.$ ), 4.67 (br s, $2 \mathrm{H}$, $\mathrm{CH}_{2}$ ), 6.98 (t, 1H, H-3'), 7.19 (t, 1H, H-5'), 7.35 (q, 1H, H-6'), 7.50 (d, $J_{o}=8.4 \mathrm{~Hz}, 2 \mathrm{H}, p$-toluene $\left.\mathrm{H}-3,5\right), 8.10\left(\mathrm{~d}, J_{o}=8 \mathrm{~Hz}, 2 \mathrm{H}, p\right.$-toluene $\mathrm{H}$ 2,6), $8.30(\mathrm{~s}, 1 \mathrm{H}$, purine $\mathrm{H}-2), 8.67(\mathrm{~s}, 1 \mathrm{H}$, purine $\mathrm{H}-8), 8.75(\mathrm{br} \mathrm{s}, 1 \mathrm{H}$, $\mathrm{NH})$. HRMS $(\mathrm{ESI}+) \mathrm{m} / z$ calcd for $\mathrm{C}_{19} \mathrm{H}_{16} \mathrm{~F}_{2} \mathrm{~N}_{5} \mathrm{O}_{2} \mathrm{~S}(\mathrm{M}+\mathrm{H})^{+}$416.0993, found 416.0978. Anal. Calcd for $\mathrm{C}_{19} \mathrm{H}_{15} \mathrm{~F}_{2} \mathrm{~N}_{5} \mathrm{O}_{2} \mathrm{~S}$ : C, 54.93; $\mathrm{H}, 3.64 ; \mathrm{N}$, 16.86; S, 7.72; Found C, 55.26; H, 3.87; N, 16.86; S, 7.61.

4.1.20.6. 6-(2,4-Dichlorobenzyl)amino-9-p-toluenesulfonyl-9H-purine (33). The compound was prepared from 6-(2,4dichlorobenzyl)amino-9H-purine (24) (100 mg, $0.33 \mathrm{mmol}$ ) according to general procedure and was purified by column chromatography (EtOAc-hexane, 1:2) to yield 33 (40 mg, 23.7\%): $\mathrm{mp}$ 180-183 ${ }^{\circ} \mathrm{C} .{ }^{1} \mathrm{H}$ NMR (DMSO-d 6 ) $\delta 2.39\left(\mathrm{~s}, 3 \mathrm{H}, \mathrm{CH}_{3}\right), 4.67(\mathrm{~d}, 2 \mathrm{H}$, $\left.\mathrm{CH}_{2}\right), 7.24\left(\mathrm{~d}, 1 \mathrm{H}, \mathrm{H}-6^{\prime}\right), 7.31\left(\mathrm{~d}, 1 \mathrm{H}, \mathrm{H}-5^{\prime}\right), 7.51\left(\mathrm{~d}, J_{o}=8.4 \mathrm{~Hz}, 2 \mathrm{H}, p-\right.$ toluene H-3,5), $7.61\left(\mathrm{~s}, 1 \mathrm{H}, \mathrm{H}-3^{\prime}\right), 8.11\left(\mathrm{~d}, J_{o}=7.6 \mathrm{~Hz}, 2 \mathrm{H}, p\right.$-toluene $\mathrm{H}-2,6), 8.28(\mathrm{~s}, 1 \mathrm{H}$, purine $\mathrm{H}-2), 8.70(\mathrm{~s}, 1 \mathrm{H}$, purine $\mathrm{H}-8), 8.79(\mathrm{br} \mathrm{s}$, $1 \mathrm{H}, \mathrm{NH}) .{ }^{13} \mathrm{C}$ NMR $\left(\mathrm{DMSO}-\mathrm{d}_{6}\right) \delta 21.87\left(\mathrm{CH}_{3}\right), 41.43\left(\mathrm{CH}_{2}\right), 120.02$, 127.96, 128.84, 129.21, 130.22, 131.03, 132.70, 133.33, 134.14, 136.09 (C in phenyl), 139.19 (C-5), 147.46 (C-8), 148.42 (C-6), 154.97 (C-2), 155.06 (C-4). HRMS (ESI+) $m / z$ calcd for $\mathrm{C}_{19} \mathrm{H}_{16} \mathrm{Cl}_{2} \mathrm{~N}_{5} \mathrm{O}_{2} \mathrm{~S}(\mathrm{M}+\mathrm{H})^{+}$ 448.0402, found 448.0408. Anal. Calcd for $\mathrm{C}_{19} \mathrm{H}_{15} \mathrm{Cl}_{2} \mathrm{~N}_{5} \mathrm{O}_{2} \mathrm{~S}$ : C, 50.90; H, 3.37; N, 15.62; S, 7.15. Found C, 51.04; H, 3.42; N, 15.44; S, 7.17 .
4.1.20.7. 6-(2-Cyclohexenylethyl)amino-9-p-toluenesulfonyl-9H-purine (34). The compound was prepared from 6-(2cyclohexenylethyl)amino-9H-purine (26) $(80 \mathrm{mg}, 0.32 \mathrm{mmol}$ ) according to general procedure and was purified by column chromatography (EtOAc-hexane, 1:2.5) to yield 34 (17 $\mathrm{mg}, 12.8 \%$ ): $\mathrm{mp}$ 161-163 ${ }^{\circ} \mathrm{C} .{ }^{1} \mathrm{H}$ NMR (DMSO-d 6 ) $\delta 1.51$ (d, $4 \mathrm{H}, \mathrm{CH}_{2}$ ), $1.88\left(\mathrm{~d}, 4 \mathrm{H}, \mathrm{CH}_{2}\right.$ ), $2.16\left(\mathrm{t}, 2 \mathrm{H}, \mathrm{CH}_{2}\right), 2.38\left(\mathrm{~s}, 3 \mathrm{H}, \mathrm{CH}_{3}\right), 3.51\left(\mathrm{q}, 2 \mathrm{H}, \mathrm{NH}-\mathrm{CH}_{2}\right), 5.36(\mathrm{~s}$, $1 \mathrm{H},=\mathrm{CH}), 7.50\left(\mathrm{~d}, J_{o}=8.4 \mathrm{~Hz}, 2 \mathrm{H}, p\right.$-toluene $\left.\mathrm{H}-3,5\right), 8.08(\mathrm{~d}, 3 \mathrm{H}, p$ toluene $\mathrm{H}-2,6, \mathrm{NH}), 8.28(\mathrm{~s}, 1 \mathrm{H}$, purine $\mathrm{H}-2), 8.61(\mathrm{~s}, 1 \mathrm{H}$, purine $\mathrm{H}-8)$. ${ }^{13} \mathrm{C}$ NMR (DMSO- $\left.\mathrm{d}_{6}\right) \delta 21.85\left(\mathrm{CH}_{3}\right), 22.55,23.06,25.31,28.44\left(\mathrm{CH}_{2}\right.$ in cyclohexenyl), $37.81\left(\mathrm{CH}_{2}\right), 39.09\left(\mathrm{NH}-\mathrm{CH}_{2}\right), 119.83$ (C in phenyl), 122.57 ( $=\mathrm{CH}$ in cyclohexenyl), 128.74, 130.98, 134.21 ( $\mathrm{C}$ in phenyl), 135.6057 (C = in cyclohexenyl), 138.66 (C-5), 147.34 (C-8), 148.21 (C-6), 155.07 (C-2), 155.26 (C-4). HRMS (ESI+) $\mathrm{m} / \mathrm{z}$ calcd for $\mathrm{C}_{20} \mathrm{H}_{24} \mathrm{~N}_{5} \mathrm{O}_{2} \mathrm{~S}(\mathrm{M}+\mathrm{H})^{+}$398.1651, found 398.1649. Anal. Calcd for $\mathrm{C}_{20} \mathrm{H}_{23} \mathrm{~N}_{5} \mathrm{O}_{2} \mathrm{~S}$ : C, 60.43; H, 5.83; N, 17.62; S, 8.07. Found C, 60.45; H, 6.09; N, 17.36; S, 7.95.

\subsubsection{6-[4-(4-Trifluorophenyl)piperazin-1-yl]-9-cyclopentyl-9H- purine (36)}

To a suspension of 6-chloro-9-cyclopentyl-9H-purine (35) [24] (106 mg, $0.47 \mathrm{mmol})$ in absolute EtOH $(5 \mathrm{ml})$ was added $\mathrm{N}-(\alpha, \alpha, \alpha-$ trifluoro-p-tolyl)piperazine ( $109.6 \mathrm{mg}, 0.47 \mathrm{mmol}$ ) and the mixture was refluxed for $10 \mathrm{~h}$. The reaction mixture was concentrated in vacuo and the residue was purified by column chromatography (EtOAc-hexane, 1:4 and 1:2) to yield 36 (140 mg, 70.6\%): mp143$145{ }^{\circ} \mathrm{C} .{ }^{1} \mathrm{H} \mathrm{NMR}\left(\mathrm{CDCl}_{3}\right) \delta 1.79-2.01\left(\mathrm{~m}, 6 \mathrm{H}\right.$, cyclopentyl $\left.\mathrm{CH}_{2}\right)$, 2.24-2.34 (m, $2 \mathrm{H}$, cyclopentyl $\left.\mathrm{CH}_{2}\right), 3.42\left(\mathrm{t}, 4 \mathrm{H}\right.$, piperazine $\left.\mathrm{CH}_{2}\right)$, 4.48 (br s, $4 \mathrm{H}$, piperazine $\left.\mathrm{CH}_{2}\right), 4.91-4.98(\mathrm{~m}, 1 \mathrm{H}$, cyclopentyl $\mathrm{CH})$, $6.98\left(\mathrm{~d}, J_{o}=8.4 \mathrm{~Hz}, 2 \mathrm{H}, \mathrm{H}-2^{\prime}, 6^{\prime}\right), 7.51\left(\mathrm{~d}, J_{o}=8.4 \mathrm{~Hz}, 2 \mathrm{H}, \mathrm{H}-3^{\prime}, 5^{\prime}\right), 7.82$ (s, $1 \mathrm{H}$, purine $\mathrm{H}-2), 8.39$ (s, $1 \mathrm{H}$, purine $\mathrm{H}-8) .{ }^{13} \mathrm{C}$ NMR (DMSO- $\mathrm{d}_{6}$ ) $\delta 24.02,32.95\left(\mathrm{CH}_{2}\right.$ in cyclopentyl $), 44.93,48.49\left(\mathrm{CH}_{2}\right.$ in piperazine $)$, $55.95\left(\mathrm{CH}_{2}\right.$ in cyclopentyl), 115.07, 120.60, 121.21 (q), 123.53 (C in phenyl), 126.71 (q) ( $\left.\mathrm{CF}_{3}\right), 136.93$ (C-5), 151.32 (C-8), 152.33 (C-6), 153.44 (C-2), 153.97 (C-4). HRMS (ESI+) $m / z$ calcd for $\mathrm{C}_{21} \mathrm{H}_{24} \mathrm{~F}_{3} \mathrm{~N}_{6}$ $(\mathrm{M}+\mathrm{H})^{+}$417.2015, found 417.2012. Anal. Calcd for $\mathrm{C}_{21} \mathrm{H}_{23} \mathrm{~F}_{3} \mathrm{~N}_{6} .0 .1 \mathrm{H}_{2} \mathrm{O}$ : C, 60.30; H, 5.59; N, 20.09. Found C, 59.99; $\mathrm{H}$, $5.64 ; \mathrm{N}, 20.21$.

\subsubsection{General procedure for the alkylation of 6-substituted purines (preparation of compounds 38-41)}

To a suspension of 6 -substituted purines $(\mathbf{1 5}, \mathbf{1 7}, \mathbf{2 2}, \mathbf{2 4})$ in dry DMF ( $5 \mathrm{ml}$ ) was added $\mathrm{NaH}$ (2 equiv, 95\%) and the mixture was stirred for $0.5 \mathrm{~h}$ at rt. Subsequently, ethyl chloroacetate (3 equiv) was added and the reaction mixture was left for $24 \mathrm{~h}$ at rt. The reaction mixture was treated with water and extracted with ether. The extract was dried over $\mathrm{Na}_{2} \mathrm{SO}_{4}$, the solvent was evaporated in vacuo, and the residue was purified by column chromatography.

4.1.22.1. 6-(3-Trifluoromethybenzyl)amino-9-(ethoxycarbonylmethyl)-9H-purine (38). The compound was prepared from 6-(3-trifluoromethybenzyl)amino-9H-purine (22) $110 \mathrm{mg}$, $0.37 \mathrm{mmol}$ ) according to general procedure and was purified by column chromatography (EtOAc-hexane, 5:1) to yield 37 (34 mg, 23.9\%): $\mathrm{mp} 184-188^{\circ} \mathrm{C}^{1}{ }^{1} \mathrm{H}$ NMR (DMSO-d 6 ) $\delta 1.21(\mathrm{t}, J=6.8 \mathrm{~Hz}, 3 \mathrm{H}$, $\left.\mathrm{CH}_{3}\right), 4.16\left(\mathrm{q}, \mathrm{J}=6.8 \mathrm{~Hz}, 2 \mathrm{H}, \mathrm{OCH}_{2}\right), 4.79$ (br s, $2 \mathrm{H}$, benzyl $\left.\mathrm{CH}_{2}\right), 5.09$ (s, 2H, NCH $), 7.52-7.62\left(\mathrm{~m}, 2 \mathrm{H}, \mathrm{H}-4^{\prime}, 6^{\prime}\right), 7.66$ (d, 1H, H-5'), 7.72 (s, $\left.1 \mathrm{H}, \mathrm{H}-2^{\prime}\right), 8.17$ (s, 1H, H-8), 8.20 (s, 1H, H-2), 8.52 (br s, 1H, NH). HRMS (ESI +$) m / z$ calcd for $\mathrm{C}_{17} \mathrm{H}_{17} \mathrm{~F}_{3} \mathrm{~N}_{5} \mathrm{O}_{2}(\mathrm{M}+\mathrm{H})^{+} 380.1334$, found 380.1331. Anal. Calcd for $\mathrm{C}_{17} \mathrm{H}_{16} \mathrm{~F}_{3} \mathrm{~N}_{5} \mathrm{O}_{2} \cdot 0.1 \mathrm{C}_{6} \mathrm{H}_{14} \cdot 0.1 \mathrm{H}_{2} \mathrm{O}: \mathrm{C}, 54.24 ; \mathrm{H}$, 4.55; N, 17.97. Found C, 54.07; H, 4.39; N, 17.72.

4.1.22.2. 6-(2,4-Dichlorobenzyl)amino-9-(ethoxycarbonylmethyl)$9 H$-purine (39). The compound was prepared from 6-(2,4dichlorobenzyl)amino-9H-purine (24) (100 $\mathrm{mg}, 0.33 \mathrm{mmol})$ 
according to general procedure and was purified by column chromatography (EtOAc-hexane, 1:1) to yield 38 (30 mg, 23.2\%): mp 199-203 ${ }^{\circ} \mathrm{C} .{ }^{1} \mathrm{H}$ NMR (DMSO-d 6 ) $\delta 1.21\left(\mathrm{t}, 3 \mathrm{H}, \mathrm{CH}_{3}\right), 4.15(\mathrm{q}, 2 \mathrm{H}$, $\mathrm{OCH}_{2}$ ), 4.70 (br s, $2 \mathrm{H}$, benzyl $\mathrm{CH}_{2}$ ), 5.07 (s, $2 \mathrm{H}, \mathrm{NCH}_{2}$ ), 7.27 (d, $\left.J_{o}=8 \mathrm{~Hz}, 1 \mathrm{H}, \mathrm{H}-6^{\prime}\right), 7.34\left(\mathrm{dd}, J_{o}=8 \mathrm{~Hz}, J_{m}=1.6 \mathrm{~Hz}, 1 \mathrm{H}, \mathrm{H}-5^{\prime}\right), 7.59(\mathrm{~d}$, $\left.J_{m}=2 \mathrm{~Hz}, 1 \mathrm{H}, \mathrm{H}-3^{\prime}\right), 8.16(\mathrm{~s}, 2 \mathrm{H}, \mathrm{H}-8, \mathrm{H}-2), 8.41$ (br s, $\left.1 \mathrm{H}, \mathrm{NH}\right) .{ }^{13} \mathrm{C}$ NMR (DMSO-d 6$) \delta 14.68\left(\mathrm{CH}_{3}\right), 41.54\left(\mathrm{NH}-\mathrm{CH}_{2}\right), 44.65\left(\mathrm{CH}_{2}\right.$-purine $\mathrm{N}), 62.07\left(\mathrm{O}-\mathrm{CH}_{2}\right), 127.96,129.18,130.12,132.57$ ( $\mathrm{C}$ in phenyl), 133.30 (C-5),136.75 (C-8), 142.25 (C-6), 153.24 (C-2), 154.82 (C-4), $168.61(\mathrm{C}=\mathrm{O})$. HRMS $(\mathrm{ESI}+) \mathrm{m} / z$ calcd for $\mathrm{C}_{16} \mathrm{H}_{16} \mathrm{Cl}_{2} \mathrm{~N}_{5} \mathrm{O}_{2}(\mathrm{M}+\mathrm{H})^{+}$ 380.0681, found 380.0670. Anal. Calcd for $\mathrm{C}_{16} \mathrm{H}_{15} \mathrm{Cl}_{2} \mathrm{~N}_{5} \mathrm{O}_{2} .0 .2 \mathrm{C}_{6} \mathrm{H}_{14}$ : C, 51.97; H, 4.51; N, 17.62. Found C, 51.84; H, 4.21; N, 17.25.

4.1.22.3. 6-[4-(2-Hydroxyethyl)piperazine-1-yl]-9-(ethoxycarbonylmethyl)-9H-purine (40). The compound was prepared from 6-[4-(2-hydroxyethyl)piperazine-1-yl]-9H-purine (15) (100 $\mathrm{mg}, 0.40 \mathrm{mmol}$ ) according to general procedure and was purified by column chromatography $\left(\mathrm{CH}_{2} \mathrm{Cl}_{2}-\mathrm{MeOH}, 2.5: 1\right)$ to yield 39 (35 mg, 26\%): mp $118-120{ }^{\circ} \mathrm{C} .{ }^{1} \mathrm{H}$ NMR (DMSO-d 6 ) $\delta 1.22(\mathrm{t}, 3 \mathrm{H}$, $\left.\mathrm{CH}_{3}\right), 2.43\left(\mathrm{t}, \mathrm{J}=6 \mathrm{~Hz}, 2 \mathrm{H}, \mathrm{CH}_{2}-\mathrm{CH}_{2}-\mathrm{OH}\right), 2.53$ (t, 4H, piperazine $\left.\mathrm{CH}_{2}\right), 3.54\left(\mathrm{q}, \mathrm{J}=6 \mathrm{~Hz}, 2 \mathrm{H}, \mathrm{CH}_{2} \mathrm{OH}\right), 4.04-4.32$ (m, 6H, piperazine $\left.\mathrm{CH}_{2}, \mathrm{OCH}_{2}\right), 4.48(\mathrm{t}, 1 \mathrm{H}, \mathrm{OH}), 5.09\left(\mathrm{~s}, 2 \mathrm{H}, \mathrm{NCH}_{2}\right), 8.17(\mathrm{~s}, 1 \mathrm{H}, \mathrm{H}-8)$, $8.23(\mathrm{~s}, 1 \mathrm{H}, \mathrm{H}-2) .{ }^{13} \mathrm{C}$ NMR (DMSO-d 6$) \delta 14.68\left(\mathrm{CH}_{3}\right), 44.65,45.07$ $\left(\mathrm{CH}_{2}\right.$ in piperazine $), 53.84\left(\mathrm{CH}_{2}-\mathrm{N}\right), 59.11\left(\mathrm{CH}_{2}\right.$-purine $\left.\mathrm{N}\right), 60.91$ $\left(\mathrm{CH}_{2}-\mathrm{OH}\right), 62.04\left(\mathrm{O}-\mathrm{CH}_{2}\right), 119.19$ (C-5), 141.04 (C-8), 151.46 (C-6), $152.68(\mathrm{C}-2), 153.79(\mathrm{C}-4), 168.55(\mathrm{C}=\mathrm{O})$. HRMS (ESI+) $\mathrm{m} / z$ calcd for $\mathrm{C}_{15} \mathrm{H}_{23} \mathrm{~N}_{6} \mathrm{O}_{3}(\mathrm{M}+\mathrm{H})^{+}$335.1832, found 335.1827. Anal. Calcd for $\mathrm{C}_{15} \mathrm{H}_{22} \mathrm{~N}_{6} \mathrm{O}_{3} .0 .46 \mathrm{CH}_{2} \mathrm{Cl}_{2}$ : C, 49.72; $\mathrm{H}, 6.19 ; \mathrm{N}, 22.50$. Found $\mathrm{C}, 49.33$; $\mathrm{H}, 6.91$; N, 22.79.

4.1.22.4. 6-[4-(4-Trifluorophenyl)piperazin-1-yl]-9-(ethoxycarbonylmethyl)-9H-purine (41). The compound was prepared from 6-[4-(4-trifluorophenyl)piperazin-1-yl]-9H-purine (17) (100 $\mathrm{mg}, 0.29 \mathrm{mmol}$ ) according to general procedure and was purified by column chromatography (EtOAc- hexane, 1:1) to yield $\mathbf{4 0}$ (30 mg, 24.1\%): mp 216-218 ${ }^{\circ} \mathrm{C} .{ }^{1} \mathrm{H}$ NMR (DMSO-d 6$) \delta 1.23(\mathrm{t}, 3 \mathrm{H}$, $\left.\mathrm{CH}_{3}\right), 3.46\left(\mathrm{t}, 4 \mathrm{H}\right.$, piperazine $\left.\mathrm{CH}_{2}\right), 4.17\left(\mathrm{q}, \mathrm{J}=6.8 \mathrm{~Hz}, 2 \mathrm{H}, \mathrm{OCH}_{2}\right), 4.37$ (br s, $4 \mathrm{H}$, piperazine $\left.\mathrm{CH}_{2}\right), 5.11\left(\mathrm{~s}, 2 \mathrm{H}, \mathrm{NCH}_{2}\right), 7.14\left(\mathrm{~d}, J_{o}=8.4 \mathrm{~Hz}, 2 \mathrm{H}\right.$, $\mathrm{H}-2^{\prime}, 6^{\prime}$ ), 7.54 (d, $\left.J_{o}=8.4 \mathrm{~Hz}, 2 \mathrm{H}, \mathrm{H}-3^{\prime}, 5^{\prime}\right), 8.22(\mathrm{~s}, 1 \mathrm{H}, \mathrm{H}-8), 8.28$ (s, $1 \mathrm{H}, \mathrm{H}-2) .{ }^{13} \mathrm{C}$ NMR (DMSO-d 6$) \delta 14.33\left(\mathrm{CH}_{3}\right), 44.34,44.95\left(\mathrm{CH}_{2}\right.$ in piperazine $), 48.48\left(\mathrm{CH}_{2}\right.$-purine $\left.\mathrm{N}\right), 62.54\left(\mathrm{O}-\mathrm{CH}_{2}\right), 115.09,119.69$, $121.23(\mathrm{q}), 123.46$ (C in phenyl), $126.73(\mathrm{q})\left(\mathrm{CF}_{3}\right), 139.11(\mathrm{C}-5), 151.37$ (C-8), 152.90 (C-6), 153.41 (C-2), 154.02 (C-4), 167.49 (C=0). HRMS (ESI+) $m / z$ calcd for $\mathrm{C}_{20} \mathrm{H}_{22} \mathrm{~F}_{3} \mathrm{~N}_{6} \mathrm{O}_{2}(\mathrm{M}+\mathrm{H})^{+} 435.1756$, found 435.1748. Anal. Calcd for $\mathrm{C}_{20} \mathrm{H}_{21} \mathrm{~F}_{3} \mathrm{~N}_{6} \mathrm{O}_{2} .0 .5 \mathrm{C}_{6} \mathrm{H}_{14} \cdot 0.28 \mathrm{CH}_{3} \mathrm{COOC}_{2} \mathrm{H}_{5}$ : C, 57.69; H, 6.07; N, 16.74. Found C, 57.80; H, 5.77; N, 16.34 .

\subsection{X-ray determination}

Single crystal measurements on $\mathbf{2 8}$ were performed on an STOE IPDS 2 two circles diffractometer equipped with graphite monochromatorMoKaradiation. Structure was solved by direct methods (SHELXS97) [48] and refined by least-squares procedures on Fsqd (SHELXL97) [49]. The refinement was made with anisotropic displacement factors for all non-hydrogen atoms. All hydrogen atoms were calculated to their idealized positions and refined as riding atoms. The geometric calculations were carried out with the program Platon [50].

\subsection{Biological evaluation}

\subsubsection{Cells and culture}

The human primary liver cancer cell lines provided from ATCC (Huh7, HepG2, Hep3B, PLC, SKHep1, Mahlavu and FOCUS) and (Snu182 and Snu475) were grown in Dulbecco's Modified Eagle's
Medium (DMEM) (Invitrogen GIBCO) and RPMI-1640 (Invitrogen GIBCO), respectively; with 10\% fetalbovine serum (FBS) (Invitrogen GIBCO), non essential amino acids, and $1 \%$ penicillin (biochrome) and incubated in $37{ }^{\circ} \mathrm{C}$ with $5 \% \mathrm{CO}_{2}$.

The cell line passage numbers were not tracked and recorded, due to the fact that drug-induced senescence is not a conclusion of telomere-shortening as if it is known to trigger replicative senescence.

Each cell line has its own splitting agenda according to its proliferation rate. All the cell lines mentioned above are adherent cells growing attached to the surface of cell culture dishes. To subculture these cells, trypsin was used to bring them into cell suspension and prior to trypsinization, the cells were washed twice with 1xPBS to get rid of the swimming (i.e. dead) cells and the cell growth medium, containing FBS. However, if the cells were incubated with test compounds, positive controls or only-DMSO, the swimming cells were collected and included to the cell lysates which were further analysed in order to assess the cytotoxicity of the test compounds accurately.

The DMSO (Sigma) was used as solvent for the compounds. The concentration of DMSO was always less than $1 \%$ in the cell culture medium. Drugs (Camptothecin, 5-FU, Doxorubicin and Staurosporine) used as positive control were from Calbiochem.

\subsubsection{Sulforhodamine B (SRB) assay for cytotoxicity screening}

All cancer cells were inoculated (2000 cell/well to 10,000 cell/ well in $200 \mu \mathrm{L} /$ well) to 96 -well plates at $37{ }^{\circ} \mathrm{C}$ in $5 \% \mathrm{CO}_{2}$. Next day, the media of the wells were refreshed and the molecules to be tested which were already dissolved in DMSO were applied directly to the first wells in calculated volumes to obtain the decided highest drug concentration. Cancer cells were also treated with DMSO-only simultaneously to avoid its solitary effect. Following the drug treatment, plates were incubated again at $37{ }^{\circ} \mathrm{C}$ in a humidified $5 \% \mathrm{CO}_{2}$ and $95 \%$ air incubator for different time periods. At the 24th, 48th and 72nd hour of drug treatment, cancer cells were fixed with ice-cold TCA ( $50 \mu \mathrm{L} /$ well) and kept at $+4{ }^{\circ} \mathrm{C}$ in dark for exactly $1 \mathrm{~h}$. TCA fixation was terminated by washing the wells with $\mathrm{ddH}_{2} \mathrm{O}$ for 5 times. Air-dried plates were stained with $0.4 \%$ sulphorhodamine B (SRB) dissolved in 1\% acetic acid solution for 10 min in dark and at room temperature. The plates which were quickly rinsed with $1 \%$ acetic acid solution to get rid of the unbound SRB dye were left to air dry. The protein-bound and dried SRB dye is then solubilized with $10 \mathrm{mM}$ Tris-Base solution (200 $\mu \mathrm{L} /$ well $)$ and homogenized on a shaker for 5-10 min. The absorbance values were obtained at $515 \mathrm{~nm}$ by means of a microplate reader and used to calculate the cell death percentage as follows: $\%$ inhibition $=100$ $\left(1-\mathrm{OD}_{\text {drug }} / \mathrm{OD}_{\mathrm{DMSO}}\right)$. The $\mathrm{IC}_{50}$ values were determined from the dose-response curves plotted as percent growth inhibition vs. drug concentration.

\subsubsection{Nuclear staining with Hoechst 33258}

Cancer cells, inoculated onto coverslips placed in 6-well plates, were treated on the next day with the decided concentrations of compounds to be tested and their DMSO-only and left to incubation at $37{ }^{\circ} \mathrm{C}$ in $5 \% \mathrm{CO}_{2}$. At the end of determined incubation period, the wells were washed with ice-cold 1xPBS and fixed with $3 \%$ formaldehyde before stained 5 min with Hoechst 33258 working solution at room temperature. The wells were destained with $\mathrm{ddH}_{2} \mathrm{O}$ for $10 \mathrm{~min}$. The nuclear morphology was examined under a fluorescent microscope.

\subsubsection{Western blot analysis}

Proteins were generated from Mahlavu and FOCUS cells treated with compound 17, 28, 36 and STS. Cells treated with these compounds and only DMSO were collected entirely; not only attached 
cells but also swimming cells were taken. Total homogenates from cells were resuspended in $50 \mathrm{mM}$ Tris- $\mathrm{HCl} \mathrm{pH} 7.4,1 \mathrm{mM}$ EDTA, $1 \mathrm{mM}$ EGTA, $150 \mathrm{mM} \mathrm{NaCl}, 1 \%$ Triton X-100, 0.1\% SDS with protease inhibitor cocktail and phosphatase inhibitors. Novex ${ }^{\mathbb{B}}$ NuPAGE ${ }^{\mathbb{B}}$ BisTris Electrophoresis system was used according to the manufacturer's protocol for all westernblotting analysis. Eventually, the expression of the protein levels was visualized via ECL + kit that is used according to the manufacturer's recommendations. Actin and calnexin proteins were used for equal loading control. Bcl-2, Cytochrome-c and PARP-1 antibodies were purchased from Santa Cruz Biotechnology.

\subsubsection{Kinase assay}

The calculated amount of cell lysate was mixed with kinase reaction buffer ( $40 \mathrm{mM}$ Tris- $\mathrm{HCl} \mathrm{pH} 7.6,20 \mathrm{mM} \mathrm{MgCl}, 0.1 \mathrm{mg} / \mathrm{ml}$ BSA) to give a final volume of $40 \mu \mathrm{L}$ in a white, 96-well, polypropylene assay plate. Then $20 \mu \mathrm{L}$ Lonza reagent (ATP detection reagent) was added. After $10 \mathrm{~min}$ dark incubation at room temperature, the luminescence was detected through a luminometer. This assay exploits intrinsic ATPase activity of a kinase that results in the phosphorylation of the target substrate in expense of the conversion of ATP to ADP. Hypothetically consumed ATP is evaluated by measuring the bioluminescence generated by the remaining ATP upon the addition of the ATP detection reagent which is utilizing the enzyme luciferase, generating light from ATP and luciferin. The cell lysates we have used in this assay were previously incubated with three purine analogues, a multi-kinase inhibitor, STS (as a positive control), and only-DMSO for $24 \mathrm{~h}$. Since we have not added any exogenous ATP and the commercial kit also do not contain, the intensity of the stable light signal emitted is linearly proportional to the concentration of ATP remained in the cell lysates after $24 \mathrm{~h}$ drug treatment. High levels of bioluminescence depict the blockage of ATP consumption; in other words, increase in the light intensity can be considered as an indirect evidence of the ATPase inhibition, hence a kinase inhibitor.

\subsubsection{Real-time cell electronic sensing (RT-CES) method for cytotoxicity profiling}

This technology utilizes the microelectronic plates (E-plates, 96well) with wells covered with gold microelectrodes at the bottom. An electric field forms between these electrodes after a low voltage application. Addition of adherent cancer cells causes changes in electrical impedance $(Z)$ which is proportional to cell numbers. These changes, displayed as Cell Index (CI) values, reveal the adhesion status of the cells in the electrode-surrounded well; in other words cell growth can be traced by increasing $\mathrm{CI}$ values due to the lack of swimming, detached cells. Proliferation of primary liver cancer cell lines was monitored in real-time cell electronic sensing RT-CES (xCELLigence-Roche Applied Science), and the CI values were measured every $30 \mathrm{~min}$ for at least 120 h.Huh7, HepG2, and Mahlavu cells were inoculated ( 2000 cell/well in $200 \mu \mathrm{l}$ ) in the E-96 plate on the xCELLigence station in $5 \% \mathrm{CO}_{2}$ at $37^{\circ} \mathrm{C}$. The $\mathrm{CI}$ values were recorded at every $30 \mathrm{~min}$. Next day, $150 \mu \mathrm{l}$ medium from each well was replaced with $100 \mu$ fresh medium and compound $\mathbf{3 6}$ applied to each well in indicated concentrations. The drug-treated E-96 plate was again placed on the RT-CES station. The CI values were recorded at every 30 min to monitor real time drug response. DMSO-only and medium-only wells were also included to avoid their solitary effects on cancer cells.

\subsubsection{Senescence associated- $\beta$-gal assay and BrdU proliferation co- staining}

Huh7 cells ( 5000 cell) inoculated to 2 identical 6-well plates on coverslips. Next day, the compound $\mathbf{3 6}$ and doxorubicin at indicated concentrations and their corresponding DMSO-only controls were applied to the plates. At the day 3 and the day 6, Senescence Associated- $\beta$-gal (SA- $\beta$-gal) assay and BrdU co-staining were established.24 h prior to the assays mediums, (both compound 36 and its corresponding DMSO-only containing) were refreshed. For one of the 6-well plates, the freshly prepared mediums were also containing $30 \mu \mathrm{M}$ BrdU (5-bromo-2-deoxyuridine). SA- $\beta$-gal and BrdU co-staining were done as described previously [51,52].

\section{Acknowledgements}

This work was supported by the Scientific and Technological Research Council of Turkey-TUBITAK (TBAG-109T987), the KANILTEK Project from the State Planning Organization of Turkey (DPT) and Bilkent University Funds. We thank to Professor HakanGoker and Dr. Mehmet Alp from Central Instrumentation Laboratory of Faculty of Pharmacy, Ankara University for NMR and elemental analyses and to Dr. Murat K. Sukuroglu from Faculty of Pharmacy, Gazi University for HRMS.

\section{References}

[1] D. Sampath, V.A. Rao, W. Plunkett, Mechanisms of apoptosis induction by nucleoside analogs, Oncogene 22 (2003) 9063-9074.

[2] I. Moriguchi, Y. Kanada, Use of van der Waals volume in structure-activity studies, Chem. Pharm. Bull. 25 (1977) 926-935.

[3] A. Brathe, G. Andresen, L-L. Gundersen, K.E. Malterud, F. Rise, Antioxidant activity of synthetic cytokinin analogues: 6-alkynyl- and 6-alkenylpurines as novel 15-Lipoxygenase inhibitors, Bioorg. Med. Chem. 10 (2002) 1581-1586.

[4] A. Brathe, L.-L. Gundersen, K.E. Malterud, F. Rise, 6-substitutedpurines as inhibitors of 15-lipoxygenase; a structure-activity study, Arch. Pharm. Chem. Life Sci. 338 (2005) 159-166.

[5] S.F. Laufer, D.M. Domeyer, T.R.F. Scior, W. Albrecht, D.R.J. Hauser, Synthesis and biological testing of purine derivatives as potential ATP-competitive kinase inhibitors, J. Med. Chem. 48 (2005) 710-722.

[6] J.A. Montgomery, K.J. Hewson, Analogs of 6-methyl-9-beta-D-ribofuranosylpurine, J. Med. Chem. 11 (1968) 48-52.

[7] G. Andersen, L.-L. Gundersen, J. Nissen-Meyer, F. Rise, B. Spilsberg, Cytotoxic and antibacterial activity of 2-oxopurine derivatives, Bioorg. Med. Chem. Lett. 12 (2002) 567-569.

[8] J.-F. Wang, L.-R. Zhang, Z.-J. Yang, L.-H. Zhang, Synthesis and biological evaluation of 6-substituted purine and 9- $\beta$-D-ribofuranosyl purine analogues, Bioorg. Med. Chem. 12 (2004) 1425-1429.

[9] M. Hocek, P. Naus, R. Pohl, I. Votruba, P.A. Furman, P.M. Tharnish, M.J. Otto, Cytostatic 6-arylpurine nucleosides. 6. SAR in anti-HCV and cytostatic activity of extended series of 6-hetarylpurine ribonucleosides, J. Med. Chem. 48 (2005) 5869-5873.

[10] T. Andjelkovic, M. Pesic, J. Bankovic, N. Tanic, I.D. Markovic, I.,S. Ruzdijic, Synergistic effects of the purine analogsulfinosine and curcumin on the multidrug resistant human non-small cell lung carcinoma cell line (NCI-H460/ R), CancerBiolTher 7 (2008) 1024-1032.

[11] D. Damaraju, V.L. Damaraju, M. Brun, D. Mowles, M. Kuzma, R.J. Berendt, M.B. Sawyer, C.E. Cass, Cytotoxic activities of nucleoside and nucleobase analog drugs in malignant mesothelioma: characterization of a novel nucleobase transport activity, Biochem. Pharmacol. 15 (2008) 1901-1911.

[12] T. Robak, A. Korycka, E. Lech-Maranda, P. Robak, Current status of older and new purine nucleoside analogues in the treatment of lymphoproliferativediseases, Molecules 14 (2009) 1183-1226.

[13] T. Robak, P. Robak, Purine nucleoside analogs in the treatment of rarer chronic lymphoid leukemias, Curr. Pharm. Des. 18 (2012) 3373-3388.

[14] M. Tuncbilek, E. BilgetGuven, T. Onder, R. Cetin-Atalay, Synthesis of novel 6(4- substituted piperazine-1-yl)-9-( $\beta$-D-ribofuranosyl)purine derivatives, which lead to senescence-induced cell death in liver cancer cells, J. Med. Chem. 55 (2012) 3058-3065.

[15] R.W. Sidwell, J.H. Huffman, G.P. Khare, L.B. Allen, J.T. Witkowski, R.K. Robins, Broad-spectrum antiviral activity of virazole: 1- $\beta$-D-ribofuranosyl-1,2,4triazole-3-carboxamide, Science 177 (1972) 705-706.

[16] E. De Clercq, S-adenosylhomocysteine hydrolase inhibitors as broad-spectrum antiviral agents, Biochem. Pharmacol. 36 (1987) 2567-2575.

[17] E. De Clercq, Carbocyclic adenosine analogues as S-adenosylhomocysteine hydrolase inhibitors and antiviral agents: recent advances, Nucleosides Nucleotides 17 (1998) 625-634.

[18] E. De Clercq, Antiviral drug discovery and development: where chemistry meets with biomedicine, Antivir. Res. 67 (2005) 56-75.

[19] E.M. Peterson, J. Brownell, R. Vince, Synthesis and biological evaluation of 5'sulfamoylated purinyl carbocyclic nucleosides, J. Med. Chem. 35 (1992) 3991-4000.

[20] A. Gangjee, A. Vasudevan, S.F. Queener, Conformationally restricted analogues of trimethoprim: 2,6-diamino-8-substituted purines as potential 
dihydrofolatereductase inhibitors from Pneumocystis carinii and Toxoplasma gondii, J. Med. Chem. 40 (1997) 3032-3039.

[21] G. Gumina, C.K. Chu, Synthesis of L-oxetanocin, Org. Lett. 4 (2002) 1147-1149.

[22] F. Bordon-Pallier, N. Jullian, P. Ferrari, A.-M. Girard, M.-T. Bocquel, J. Biton, N. Bouquin, J.-L. Haesslein, Inhibitors of Civ1 kinase belonging to 6aminoaromatic-2-cyclohexyldiamino purine series as potent anti-fungal compounds, Biochim. Biophys. Acta 1697 (2004) 211-223.

[23] P.R. Patel, C. Ramalingan, Y.T. Park, Synthesis and antimicrobial evaluation of guanylsulfonamides, Bioorg. Med. Chem. Lett. 17 (2007) 6610-6614.

[24] M. Tuncbilek, Z. Ateş-Alagöz, N. Altanlar, A. Karayel, S. Ozbey, Synthesis and antimicrobialevaluation of some newsubstituted purine derivatives, Bioorg. Med. Chem. 17 (2009) 1693-1700.

[25] B. Ewald, D. Sampath, W. Plunkett, Nucleoside analogs: molecular mechanismssignaling cell death, Oncogene 27 (2008) 6522-6537.

[26] J.G. Kuhn, Fluorouracil and the new oral fluorinated pyrimidines, Ann. Pharcother. 35 (2001) 217-227.

[27] G. Escherich, S. Richards, L.J. Stork, A.J. Vora, Childhood Acute Lymphoblastic Leukaemia Collaborative Group (CALLCG), Meta-analysis of randomised trials comparing thiopurines in childhood acute lymphoblastic leukaemia, Leukemia 25 (2011) 953-959.

[28] E. Lech-Maranda, A. Korycka, T. Robak, Pharmacological and clinical studies on purine nucleoside analogs- new anticancer agents, Mini Rev. Med. 6 (2006) $575-581$.

[29] P.K. Wilson, S.P. Mulligan, R.I. Christopherson, Metabolic response patterns of nucleotides in B-cell chronic lymphocytic leukaemias to cladrabine, fludarabine and deoxycoformycin, Leuk. Res. 28 (2004) 725-731.

[30] Y. Kurihara, K. Eqawa, S. Kunimoto, T. Takeuchi, K. Nose, Induction of p16/ INK4a gene expression and cellular senescence by toyocamycin, Biol. Pharm. Bull. 25 (2002) 1272-1276.

[31] S. Amatori, I. Bagaloni, D. Viti, M. Fanelli, Premature senescence induced by DNA demthylatingagente (decitabine) as therapeutic option for malignant pleural mesothelioma, Lung Cancer 71 (2011) 113-115.

[32] D. Murray, R. Mirzayans, Role of therapy-induced cellular senescence in tumor cells and its modification in radiotherapy: the good, the bad and the ugly, J. Nucl. Med. Radiat. Ther. S6 (2013) 1-7.

[33] G. Saretzki, Cellular senescence in the development and treatment of cancer, Curr. Pharm. Des. 16 (2010) 79-100.

[34] Q. Yan, N. Wajapeyee, Exploiting cellular senescence to treat cancer and circumvent drug resistance, Cancer Biol. Ther. 9 (2010) 166-175.

[35] A. Forner, J.M. Llovet, J. Bruix, Hepatocellular carcinoma, Lancet 379 (2012) $1245-1255$

[36] P.R. Galle, Sorafenib in advanced hepatocellular carcinoma - we have won a battle not the war, J. Hepatol. 49 (2008) 871-873.

[37] C. Chen, Y. Chen, J. Zhou, C.A. Wu, Novel fluorescent array for mercury (II) ion in aqueous solution with functionalized cadmium selenidenanoclusters, Anal. Chim. Acta 569 (2006) 58-65.
[38] A. Scozzafava, A. Mastrolorenzo, C.T. Supuran, Antimycobacterial activity of 9 sulfonylated/sulfenylated-6-mercaptopurine derivatives, Bioorg. Med. Chem. Lett. 11 (2001) 1675-1678.

[39] J.L. García-Giménez, G. Alzuet, M. Gonzalez-Alvarez, A. Castiñeiras, M. LiuGonzalez, J.A. Borras, Dinuclearcopper(II) complex with adeninate bridge ligands and prominent DNA cleavage activity. Structural and spectroscopic characterization and magnetic properties, Inorg. Chem. 46 (2007) 7178-7188.

[40] A. Lundin, Applications of firefly luminesence, in: M. Deluca, W. McElroy (Eds.), Bioluminescence and Chemiluminescence: Basic Chemistry and Analytical Applications, Academic Press, New York, 1981, pp. 187-196.

[41] P. Singh, B.J. Harden, B.J. Lillywhite, P.M. Broad, Identification of kinase in hibitors by an ATP depletion method, Assay. Drug Dev. Technol. 2 (2004) $161-169$.

[42] F. Buontempo, T. Ersahin, S. Missiroli, S. Senturk, D. Etro, M. Ozturk, S. Capitani, R. Cetin-Atalay, M.L. Neri, Inhibition of aktsignaling in hepatoma cells induces apoptoticcell death independent of Akt activation status, Invest New. Drugs 29 (2010) 1303-1313.

[43] S. Senturk, M. Mumcuoglu, O. Gursoy-Yuzugullu, B. Cingoz, K.C. Akcali, M. Ozturk, Transforming growth factor-beta induces senescence arrest in hepatocellular carcinoma cells and inhibits tumor growth, Hepatology 52 (2010) 966-974.

[44] C. Nardella, J.G. Clohessy, A. Alimonti, P.P. Pandolfi, Pro-senescence therapy for cancer treatment, Nat. Rev. Cancer 11 (2011) 503-511.

[45] S.M. Tisdale, J. Van Tuttle, M.J. Slater, S.M. Daluge, W.H. Miller, T.A. Krenitsky, G.W. Koszalka, Method for the treatment of protozoa infections with $2^{\prime}$ deoxy-2'-fluoropurine nucleosides. US Patent 5,420,115, 1995

[46] S.H. Burstein, H.J. Ringold, N,N-Bridged derivatives of adenine, Can. J. Chem. 40 (1962) 561-564

[47] K. Dolezal, I. Popa, V. Krystof, L. Spichal, M. Fojtikova, J. Holub, R. Lenobel, T. Schmülling, M. Strnad, Preparation and biological activity of 6-benzylaminopurine derivatives in plants and human cancer cells, Bioorg. Med. Chem. 14 (2006) 875-884.

[48] G.M. Sheldrick, SHELXS97. Program for the Solution of Crystal Structure University of Göttingen, Germany, 1997.

[49] G.M. Sheldrick, SHELXL97. Program for the Refinement of Crystal Structures, University of Göttingen, Germany, 1997.

[50] A.L. Spek, PLATON, an integrated tool for the analysis of the results of a single Crystal structure determination, ActaCryst A46 (1990) C34.

[51] G.P. Dimri, X. Lee, G. Basile, M. Acosta, G. Scott, C. Roskelley, E.E. Medrano M. Linskens, I. Rubelj, O. Pereira-Smith, M. Peacocke, J.A. Campisi, Biomarkerthatidentifiessenescenthumancells in cultureand in aging skin in vivo, Proc. Natl. Acad. Sci. U. S. A. 92 (1995) 9363-9367.

[52] N. Ozturk, E. Erdal, M. Mumcuoglu, K.C. Akcali, O. Yalcin, S. Senturk, A. ArslanErgul, B. Gur, I. Yulug, R. Cetin-Atalay, C. Yakicier, T. Yagci, M. Tez, M. Ozturk, Reprogramming of replicative senescence in hepatocellular carcinomaderived cells, Proc. Natl. Acad. Sci. U. S. A. 103 (2006) 2178-2183. 